\title{
NEW MEDIA, YOUTH, AND PARTICIPATORY CULTURE: INTERNET MEMES DURING THE IMPEACHMENT PROCESS IN BRAZIL
}

\author{
by \\ IAGO BUENO BOJCZUK CAMARGO
}

\begin{abstract}
A THESIS
Presented to the School of Journalism and Communication and the Robert D. Clark Honors College

in partial fulfillment of the requirements for the degree of Bachelor of Arts

June 2018
\end{abstract}




\section{An Abstract of the Thesis of}

Iago Bueno Bojczuk Camargo for the degree of Bachelor of Arts in the School of Journalism and Communication to be taken June 2018

Title: New Media, Youth, and Participatory Culture: Internet Memes during the Impeachment Process in Brazil

Approved:

HyeRyoung Ok, Ph.D.

This thesis examines the relationship between youth and new media practices in fostering political participation in online spaces during the impeachment proceedings against Dilma Rousseff, Brazil's first woman president. In the midst of the political turmoil revolving around the 2016 impeachment case in Brazil, young people actively adopted Social Network Sites (SNS) as vehicles to circulate political user-generated memes. Despite the fact that Brazil is one of the largest democracies in the world, the country still has a long way to go in diversifying its media channels to allow impactful youth participation in the public opinion. However, the number of youth in online spaces continue to increase, as Brazil becomes one of the most active countries on SNS, despite the economic recession. Aside from their reoccurring reactionary, ahistorical, tautological, and superficial elements, Internet memes about the impeachment represent an emerging type of digital labor that is not driven by a particular media text as most memes. Instead, these Internet memes largely gain symbolic meaning and popular appeal through the merging of seemingly unrelated juxtaposition of visual texts, hero and anti-hero characters, and dramatic plotlines. In conjunction, these memes 
demonstrate to be deeply rooted in the local tradition of cultural cannibalism and popular imagination drawn from Brazilian telenovela conventions. Considering memes both as participatory culture artifacts and as a paratexts for civic engagement, this new gateway for participation suggests that Brazilian youth are not passive consumers of traditional media, but rather active, creative, and influential in online spaces and, potentially, in the public sphere.

Keywords: Internet memes, Brazil, youth, new media practices, Dilma Rousseff, impeachment, civic participation, self-irony, digital activism, and online spaces. 


\section{Acknowledgements}

First and foremost, I would like to express my sincere gratitude to my primary advisor Dr. HyeRyoung Ok, from the School of Journalism and Communication and the Department of Cinema Studies, for the continuous support of a research idea that initially seemed difficult to pursue scholastically. Dr. Ok's expertise on transmedia and transnational cultures coupled with her steady patience, insightful comments, and high standards have constantly challenged me to embark on an academic journey that I did not know that existed before. Without her support, I would not have been able to go through this strenuous but rewarding process. I would like to extend my sincere gratitude to Professor Erin Hanna, my second reader, and to Professor Trond Jacobsen, my Clark Honors College representative, for dedicating their time to serve on my thesis committee.

Besides faculty members, I would like to thank my friends Camila de Moraes and Vítor Vasconcelos for the uncountable number of hours spent on the phone talking in Portuguese about memes and our country's complex political scenario. The distance between Brazil and the United States never seemed so short—physically, politically, and metaphorically. I also want to underscore my gratitude to my closest college friends Sara Fatima, Nelson Perez Catalan, Srushti Kamat, and Kearney Newman. Their friendship, keen humor, and intelligence impacted me in so many levels in the writing process of this project—including the various moments when they used to make fun of me for writing a thesis on Brazilian memes. 
Furthermore, I want to thank my fellow colleagues in the Humanities Undergraduate Research Fellowship (HURF) for the stimulating experiences, for the interesting discussions we had during weekly meetings, and for all the fun and anxiety we shared during the undergraduate research symposium at the University of Oregon in 2017. The fellowship support from made an enormous difference during the early stages of this project when I was still a junior.

It is also important to mention that I consider this research project to be a turning point in my undergraduate career because it proved me the excitement associated with interdisciplinary questions. This thesis empowered me to leave my comfort zone and ask challenging questions that may help me and others unravel the complexities concerning new media practices in Brazil as well as better understand the interplay between technology and cultures of the Global South. Additionally, it is thanks to the many generous people and valuable opportunities during my time as an undergraduate student at the University of Oregon's Robert D. Clark Honors College and School of Journalism and Communication that this project led me to consider applying to the Comparative Media Studies Graduate Program at the Massachusetts Institute of Technology (MIT), where I am heading to in the fall of 2018.

I would also like to thank the creators of this thesis template, the CHC Librarian Ms. Miriam Rigby and the CHC Academic \& Thesis Programs Manager Ms. Miriam Jordan. Ms. Jordan's patience, kindness, and guidance through this process played a significant role in my time at the CHC. Whenever I missed Latin America, Ms. Jordan was the one I could talk to and also the one who would make me feel home. 
Last but not the least, I would like to thank my family for always supporting me not only throughout this project, but also in pursuing my academic, personal, and professional goals while studying abroad in the United States. It is thanks to mother, Stella Maris Bueno, and my father, Eunek de Oliveira, that I grew up as a curious person. My parents' consistent hard work and perseverance toward a better future laid the foundation that enabled me to ultimately write this thesis in a foreign language and become the first one in my family to receive a bachelor's degree. I am beyond grateful! Por agora e para sempre, meu muito obrigado! 
"Só a ANTROPOFAGIA nos une. Socialmente. Economicamente. Filosoficamente. Única lei do mundo. Expressão mascarada de todos os individualismos, de todos os coletivismos.

De todas as religiões. De todos os tratados de paz.

Tupi, or not tupi that is the question."

"Only Cannibalism unites us. Socially. Economically. Philosophically. The unique law of the world. The disguised expression of all individualisms, all collectivisms.

Of all religions. Of all peace treaties.

Tupi or not Tupi that is the question."

Oswald de Andrade, Em Piratininga, Ano 374 da Deglutição do Bispo Sardinha. Revista de Antropofagia, Ano 1, No. 1, maio de 1928 
"Brazil is an enormous inside joke, and the Internet is a mass conversation. Brazil was the Internet before the Internet existed."

\author{
John Perry Barlow
}

Fellow Emeritus at Harvard University's Berkman Center for Internet and Society 


\section{Table of Contents}

Chapter 1: Introduction $\quad 1$

Chapter 2: Media Landscape in Brazil 6

Information and Communication Technologies (ICTs) and Television 6

Brazilian New Media Practices and the Orkut Rule 10

Chapter 3: Internet Memes: Artifacts of Participatory Culture 18

Defining Internet Memes 20

Cultural Relevance of Facebook and Twitter in Brazil's Online Spaces 22

Chapter 4: Case Study: The 2016 Impeachment Through the Lens of Memes 28

$1^{\text {st }}$ Memetic Wave: April 17th 33

$2^{\text {nd }}$ Memetic Wave: May 9 $9^{\text {th }}$ and May 12th 37

$3^{\text {rd }}$ Memetic Wave: August 31 $1^{\text {st }} \quad 40$

Chapter 5: Popular Culture and Intervisuality: The Making of Symbolic Meaning 46 Memes as Paratexts $\quad 46$

Life is a Drama: Agency, Telenovela, and Cannibalism 54

Chapter 6: Conclusion: Toward Participatory Politics 71

$\begin{array}{ll}\text { Bibliography } & 75\end{array}$ 


\section{List of Figures}

Figure 1: Meme from the III World War of Memes \#TerceiraGuerraMemeal (a) 25

Figure 2: Meme from the III World War of Memes \#TerceiraGuerraMemeal (b) 26

Figure 4: Christ the Redeemer, the Islamic State (ISIS), and the Olympic Games 27

Figure 3: Christ the Redeemer and Pokémon Go \#Rio2016 27

Figure 5: Organizing Memes in Folders \#ImpeachmentDay 31

Figure 6: Depiction of Celebrities in the Congress 34

Figure 8: Voting session as a TV show 35

Figure 7: "Live from Brasília" with TV characters 35

Figure 9: Mickey, Fofão, Spider-Man, Captain America, and the Islamic State (ISIS) 36

Figure 10: Dilma Rousseff and Beyoncé's Formation. 38

Figure 11: Dilma Rousseff vs. Michel Temer in Miss Universe 39

Figure 13: Dilma as President vs. Dilma as part of the working class 40

Figure 12: "I came like a Temer Ball"

Figure 15: Michel Temer as Usurpadora \#ImpeachmentDay 41

Figure 14: Dilma as an Ice Cream Seller \#TchauQuerida 41

Figure 16: Portrayal of Dilma in the Harry Potter Universe 42

Figure 17: Depiction of right-wing politicians as Harry Potter's enemies 43

Figure 18: Depiction of Voldemort and his allies as Dilma's enemies 44

Figure 19: Brazilian Congress and House of Cards 49

Figure 20: Depiction of Michel Temer as Frank Underwood 50

Figure 21: Satirical depiction of Brazil without Dilma Rousseff 53

Figure 22: Depiction of the Impeachment via Pokémon Go 53

Figure 23: Tutorial on How to Reestablish Democracy in Brazil 54

Figure 24: Picture of the Cannibalist Manifesto published in 1928. 


\section{List of Tables}

Table 1: Kenneth Burke's Dramatistic Pentad 57

Table 2: 1st Memetic Wave - Prelude $\quad 58$

Table 3: 2nd Memetic Wave - Central phase 59

Table 4: 3rd Memetic Wave - Ultimate phase 59

Table 5: Telenovela plotline conventions breakdown by Brazilian essayist Decio Pignatari (1984) 


\section{Chapter 1: Introduction}

Nearly a century ago, Walter Lippman argued that the news media were the primary source of what he regarded as the 'pictures in our heads'. ${ }^{1}$ The implications of this concept engendered a handy intellectual journey concerning agenda-setting and the social science theories that emerged from thereabout. In our current global media systems, however, the so-called 'pictures in our heads' are not only shaped by news media but also increasingly challenged by the active role in which youth play throughout our networked society. Youth, unlike previous generations, now produce media content that quickly travels around the globe, through satellites and digital screens, inciting discussions in online and offline spaces, urban centers and rural areas, classrooms and dinner tables - from Latin America to Africa. Partially as a result of the development of personal computing, new media play a crucial role in enabling youth to shape the 'pictures in our heads' at a breakneck speed. This is mostly because young people are able to centralize the important and unique perspectives, experiences and voices - particularly those whose images are distorted or under-represented in conventional and mass media. When it comes to engaging with politics in online spaces, the fast-evolving role of youth will continue to take unique forms and allow for discussions that are often overlooked.

In 2016, while most of the American media outlets focused on the coverage of the presidential candidacy of Donald Trump, a phenomenon both unprecedented and unusual captured people's attention in Brazil. Dilma Rousseff, the country's first woman president, faced accusations of political wrongdoings that led to an

${ }^{1}$ Lippmann, Walter. 1922. Public Opinion. New York: Harcourt, Brace. 
impeachment. As a response to such escalating political crisis, Brazilian youth throughout the country filled online spaces with thousands of memes as a way to engage in discussions about the impeachment. Originally defined as a transmission of a cultural unit, memes have become part of a common media practice in youth digital culture. ${ }^{2}$ Memes are now part of the everyday use of social media due to a variety of reasons such as readability and humor, as well as the opportunity youth have in easily creating, recreating, and circulating content. As a matter of fact, recent data from Google indicates that, in 2016, the search for the word "memes" surpassed the search for the word "Jesus" on the Internet. ${ }^{3}$ Although the meme phenomenon is frequently observed in many countries around the world, I argue that the practice is particularly attractive in the case of Brazil given the country's hyper-social culture and its openness in appropriating, correlating, and critiquing facts or situations using highly unrelated media elements.

Internet memes, as a new media practice, are possible because of media technologies. In general, one can associate the broader terminology of media technologies with satellites, television, the Internet, social media, and mobile phones as most prominent examples. Accordingly, the dramatic increase of Internet access in the country since the first decade of the $21^{\text {st }}$ century reflects the impact of the rapid development of Information and Communication Technologies (ICTs), which reconfigured the media landscape. With an increased subscription to the Internet and

\footnotetext{
${ }^{2}$ Shifman, Limor. Memes in Digital Culture. MIT Press Essential Knowledge Series. Cambridge, Massachusetts: MIT Press, 2014, passim.

${ }^{3}$ Farber, Madeline. "The Internet Officially Cares More About Memes Than Jesus." Google Trends 2016: Memes More Popular Than Jesus | Fortune.com. October 27, 2016. Accessed May 14, 2017. http://fortune.com/2016/10/27/google-trends-memes-jesus/.
} 
cultural uptake of Social Network Sites (SNS), Internet memes became one of the most popular and significant new media practices among Brazilian youth. Despite the humorous and superficial elements featured in their texts, memes in Brazil often play a significant role in displaying public discourses that are relevant to social realities but ignored by traditional media. The relationship between Internet memes during the impeachment and the following discussions in the public sphere serve as a critical example of how new media practices shape relevant discourses among young people. Hence, this project's starting point lies in the premise that memes reflect not only a specific situation within a given context but one that also is deeply ingrained in the culture and media landscape from where it emerges.

Having said that, this research examines the intersection of the current new media landscape, the youth engagement in online spaces, and the use of Internet memes through participatory culture during the impeachment proceedings against Dilma Rousseff. A close analysis of the user-generated memes in reaction to the 2016 presidential impeachment will show how the relationship between networked sociality, cultural cannibalism, and telenovela conventions help contextualize the relevance of Internet memes in Brazil. To do so, I attempt to address the following questions: What constituted the key sociocultural elements that were juxtaposed in Internet memes circulated during the 2016 impeachment? How did the memetic discourse in online spaces evolve and reflect symbolic meaning in such context?

As an attempt to contextualize Internet memes as paratexts for civic engagement, this study focuses on examples produced in the months of April, May, and August of 2016. The choice for these dates reflects pivotal moments during the political 
turmoil covered by traditional media outlets - the movement of the impeachment trial from the parliament's lower house to the senate, more broadly. More importantly for the goal of this research, these three moments also reflect the three characterized waves of political memes around the discussion of the impeachment, which captivated the attention of traditional newspapers and popular blogs. This is not intended to provide a strict division, but rather to find the main trends observed in specific periods when the political discussions became the center of attention both in online and offline spacesfrom blogs to newspapers. The periodization is, therefore, organized to showcase how the memetic discussion has changed over time, including its adaptation, appropriation, and rapid response to media texts outside the impeachment case. To minimize random selection of memes and potential research bias, I attempt to look at the general identification of memes usually associated with popular hashtags that were in favor, neutral, and against the impeachment procedures throughout these three identified waves.

The relevance of political memes in inciting discussions in the public sphere suggests that the creative appropriation of new media will continue to find unique forms in Brazil's rich cultural sphere. This is largely because more people nowadays have the technologic resources to engage in online discussions through participatory culture, regardless of their socioeconomic class, physical address, or level of education. Such new media practice will potentially require new hybrid forms of media literacy that allow for a more active SNS participation when discussing topics such as politics. While I often refer to statistical information in the first chapters, this research is qualitative in its essence. Thus, there are three main steps of this qualitative approach: i) 
A close analysis of popular memes that went viral on Facebook, Twitter and were reported in traditional Newspapers or well-accessed blogs; ii) Identification of storytelling trends observed in each memetic wave (April, May, and August); and iii) Critical application of Kenneth Burke's dramatistic pentad to contextualize the youth agency in relation to Brazil's culture and collective imagination.

Although not all memes reflected youth's will and sagacity in discussing politics, the collective debate through memes during the impeachment suggests that Brazilian youth can reflect about issues of democracy via self-irony in a way that potentially triggers further discussions in the public sphere. This suggests that Brazilian youth are not passive consumers of traditional media, but rather active, creative, and influential in online spaces and, potentially, in the public sphere.

Regardless of the media message of each specific meme created as a response to the impeachment process, the youth creative process coupled with the juxtaposition of these texts in memes shared on Facebook and Twitter represented a diffusion of ironical ideas that operate under high intertextuality, dramatism, and powerful dialogue. It is certain that the legacy of the memes circulated during the 2016 impeachment will impact the way scholars of the future study youth engagement and the burgeoning of new media practices. All in all, it is my hope that this thesis will help instigate a reconsideration of the role of youth in online spaces not only in terms of entertainment, socialization or even slacktivism, but rather as media activists in critically reforming communication and giving sociological values to the 'pictures in our heads,' even if that is through a silly meme. 


\section{Chapter 2: Media Landscape in Brazil}

\section{Information and Communication Technologies (ICTs) and Television}

Both for Brazilians and non-Brazilians, the notion that characterizes Brazil as "the country of the future" has for long permeated the imaginary of many, either for the country's unique multicultural profile or environmental and economic potential. As the fifth largest country in the world, Brazil's rapid development of Information and Communication Technologies (ICTs) have transformed the country into a leading figure in the digital media revolution in Latin America. ${ }^{4}$ Consequently, Brazil is also the fifth among countries whose people spend the most time surfing online. ${ }^{5}$ As in many countries in the Global South, the growth of ICTs in Brazil has impacted all aspects of the social and economic life, including new forms of media production and messages across diverse platforms - from radio or TV to mobile phone applications. The development of ICTs and subsequent cultural appropriation of new media in Brazil have also influenced traditional media outlets to adapt their practices to serve a rapidlychanging new media environment. As a result, such transformation arguably requires innovative forms of digital media literacy from users who generally spend a considerable amount of time producing, consuming, and sharing content through online spaces.

\footnotetext{
4 The United Nations Education, Scientific, and Cultural Organization (UNESCO) defines ICT as the combination of informatics technology with other related technologies, specifically communication technology.
} 
While many argue that ICTs represent an opportunity for innovation toward a sustainable development, the digital divide is still responsible for hindering economic growth in many regions of the world. ${ }^{6}$ A 2011 report by the European Commission assert that the ICT-enabled fast innovation across Brazil's digital media landscape intensified since the 1990s when the neoliberal ideology spurred the expansion of the technological development across Latin America. During the same period, the relative value of the ICT market almost doubled in Brazil. ${ }^{7}$ Despite the current economic recession and sociopolitical turmoil in the aftermath of the 2016 impeachment, the Brazilian ICT sector continues to expand as it offers growing opportunities for foreign investment and technological innovations. Although the digital divide is more prevalent in rural and less developed areas as well as across lower-income classes, the ICT development in Brazil has enabled more people to access to information and thus participate in this emerging landscape that for long has been exclusive to certain privileged groups.

If television and radio were the only channels of information for a marginalized person, today that same person has a higher probability to access the Internet via a smartphone. With this in mind, the access to the information on the Internet and the contact with other people results in an increased awareness of the user's socioeconomic circumstances while it allows for more participation in online spaces - be it via SNS or

\footnotetext{
${ }^{6}$ Tongia, Rahul, Eswaran Subrahmanian, and V. S. Arunachalam. Information and Communications Technology for Sustainable Development: Defining a Global Research Agenda. Report. Carnegie Mellon University. Mumbai: Allied Publishers PVt. Ltd., 2004. 29-30. http://www.cs.cmu.edu/ rtongia/ICT4SD_Full_Book.pdf

${ }^{7}$ Simon, Jean P. The ICT Landscape in BRICS Countries: Brazil, India, China. Report. Institute for Prospective Technological Studies, European Commission. Luxembourg: Publications Office of the European Union, 2011. P. 8.
} 
any other community-based website. In a 2014 BuzzFeed article, John Perry Barlow, a former Fellow Emeritus at Harvard University’s Berkman Center for Internet and Society, wrote "Brazil is an enormous inside joke, and the Internet is a mass conversation. Brazil was the Internet before the Internet existed." ${ }^{8}$ Hence, the high cultural prominence of SNS in Brazil has largely resulted from the combination of the fast ICT development coupled with the striking sociality of the Brazilian culture performed by the predominance of a young population. Despite the fact that the large territory of Brazil has always presented additional structural challenges for ICT development, the media landscape in the country is similar to the majority of Latin American nations, having the television as the driving cultural force. In fact, it is also television that has dominated the media landscape and shaped various cultural aspects of the everyday life and national identity since the modernization period in the 1950 s. $^{9}$

The domination of television in Brazilian culture results partially from its unique industrial structure that is governed by the monopoly of Rede Globo, Latin America's largest media corporation. In the globalization era, ICTs expand not only the access to information across national borders but also help enlarge the economic growth as the improvement for local media production develops. Accordingly, ICTs bring new opportunities and challenges for citizens, government, and business, such as TV

\footnotetext{
${ }^{8}$ Ruvolo, Julie. "Why Brazil Is Actually Winning The Internet.” BuzzFeed. June 29, 2014. Accessed April 17, 2018. https:/www.buzzfeed.com/jruv/why-brazil-is-actually-winning-theinternet?utm_term=.qeaBVR0RXo\#.rlYqVk5kew.

${ }^{9}$ Television practices started in in Brazil when Assis Chautebriand created the first channel called Rede Tupi in São Paulo in 1950. In fact, television became a mass medium in Brazil earlier than in most developing countries. The uptake of color television marked a significant transition in the country's history as it enabled nation-wide 'live' experience of the World Cup, the Vietnam War, the Beatles, and thus the formation of national culture within a global context.
} 
networks. ${ }^{10}$ For instance, it is well discussed how modern ICTs and social media contributed to the civic movement during the Arab Spring in 2010, fostering political changes across the MENA region. Al-Jazeera, for example, has played a significant role in connecting the Arab-speaking world by focusing on events of interest across the region rather than those specific to one country. To illustrate that, studies show that Arabs who consume Al-Jazeera are more likely to view their primary identity as that of Muslims, rather than as citizens of their country. ${ }^{11}$ This suggests that Al Jazeera plays a pivotal role in shaping political and cultural identities of Arab Muslims not only amongst themselves, but also in relation to the outside world. Similarly, Brazilian television has played an enormous role in creating a Portuguese-speaking identity across national borders, considering that countries such as Angola, Mozambique, and Portugal are big consumers of media content from Rede Globo, well-known for the telenovela production in Brazil. ${ }^{12}$

Despite the ICT development and the Internet penetration, television continues to be the primary medium of communication most frequently used by Brazilians. According to the 2014 census by the Brazilian Institute of Geography and Statistics (IBGE), television equipment was present in 97.1\% of the 67 million houses in Brazil. The census also indicated that there were more TV sets than fridges in most of the

\footnotetext{
10 Tsang, Flavia, Ohid Yaqub, Desiree Van Welsum, Tony G. Thompson-Starkey, and Joanna Chataway. The Impact of Information and Communication Technologies in the Middle East and North Africa. Report. World Bank. Accessed November 05, 2016.

11 “Al Jazeera Helps Shape Political Identity of Arabs, Study Finds.” Ohio State University. Accessed March 05, 2017. https://news.osu.edu/news/2010/11/18/arabnetworks/

12 "Rede Globo emite conteúdos em Angola e Moçambique exclusivamente pela ZAP." SAPO 24. June 02, 2015. Accessed March 05, 2017. http://24.sapo.pt/noticias/nacional/artigo/rede-globo-emiteconteudos-em-angola-e-mocambique-exclusivamente-pela-zap_19311208.html.
} 
Brazilian households. ${ }^{13}$ Additionally, the 2015 Brazilian Research of Media report shows that $95 \%$ of Brazilians watch TV programs regularly and $74 \%$ watch TV every day. In terms of gender and age, the data indicate that women spend more time than men, and people between 16 and 25 years old tend to watch less TV than the elderly. The cultural impact of television and, in particular, telenovela, is emblematic of the sprouting of a national identity. One possible implication in this shift lies in the fact that the access to culture is no longer a monopoly of intellectuals, politicians or the elite, that is, the ones at the commanding positions in the Brazilian social order. ${ }^{14}$ While television has played a pervasive role in the cultural life of Brazilians, youth are increasingly more active in other media platforms such as Facebook, YouTube, and WhatsApp, where they can chat with friends and establish relationships in online spaces. It is in these interactions via new media that these youth texts gain symbolic meaning. This is key information for the forthcoming chapters discussing memes in online spaces as an emerging gateway for youth participation.

\section{Brazilian New Media Practices and the Orkut Rule}

It is undeniable that the ICT advancement in Brazil has enlarged the ways in which youth produce, consume, and circulate new media. Although the definition of new media is vastly complex, the foremost terms in discourses about new media comprise the following features: digital, interactive, hypertext, networked, and

\footnotetext{
${ }^{13}$ Flávia Villela, "IBGE: 40\% Dos Brasileiros Têm Televisão Digital Aberta." Agência Brasil. Acessed March 12, 2017.

${ }^{14}$ Lopes, Maria Immacolata Vassalo de Lopes I. V. "Telenovela as a Communicative Resource." Matrizes 3, no. 1 (2009): 3. Accessed March 4, 2017.
} 
simulated. ${ }^{15}$ Considering social media as a computer-mediated space, there are arguably many new media practices that are worth analyzing, but I focus essentially on social media and Internet memes. One of the interesting aspects of Brazil's social media use is that even though the digital divide prevails, the Internet exposure rate is intense with $76 \%$ of users accessing the Internet every day and spending an average of five hours on weekdays. ${ }^{16}$ In 2015 , about $60 \%$ of the Brazilian population had access to the Internet. Conversely, in 2006, that percentage was under $30 \%$. In comparison to the neighboring countries in Latin America, the Internet penetration in Chile, Argentina, and Uruguay is higher than the one observed in Brazil. However, according to recent data from the International Telecommunication Union (ITU), UN specialized agency for ICTs, the penetration of high-speed Internet in Brazil shows a different pattern from the one observed in other countries. For instance, the fixed broadband subscription counts for only about $13 \%$ of the population, whereas in the U.S. the subscription is about $32 \%$. This characteristic is observed partially due to the high price of broadband costs in Brazil. It is, in fact, the mobile phones that drive the rapid growth of high-speed internet service. As a matter of fact, $41 \%$ of Brazilians use the $3 \mathrm{G}$ technology, and there is a strong tendency that the $4 \mathrm{G}$ connection will continue improving. ${ }^{17}$ Once again, such configuration reflects Brazil's rapid ICT development and uptake of the latest

\footnotetext{
${ }^{15}$ Lister, M. (2009). New media: A critical introduction (2nd ed.). Milton Park, Abingdon, Oxon; New York, N.Y.: Routledge, p. 13.

${ }^{16}$ Pesquisa Brasileira de Mídia 2015: Hábitos de Consumo de Mídia Pela População Brasileira. Publication. Secretaria de Comunicação Social, Presidência da República. Brasília: Secom, 2014. 47-64.

17 "Fixed broadband subscriptions (per 100 people)." Fixed broadband subscriptions (per 100 people) Data. 2015. Accessed March 05, 2017. http://data.worldbank.org/indicator/IT.NET.BBND.P2?end=2015\&locations=BR\&start=1990\&view=cha rt.
} 
technologies such as the mobile phone, which makes Brazil the $5^{\text {th }}$ largest market for smartphones in the world ${ }^{18}$ and where mobile will make up $56 \%$ of total internet access revenue by $2018 .^{19}$

When associated with the rapid development of ICT infrastructure, the cultural openness for appropriating global trends is crucial in understanding the significance of online-based interactions among Brazilian youth. Particularly among young people, recent reports show that $90 \%$ of Brazilian youth between nine and seventeen years old are connected to SNS. ${ }^{20}$ The social media impact on popular culture is so prominent that Brazil has been labeled as the "Social Media Capital of the Universe" by the Wall Street Journal. ${ }^{21}$ Additionally, the Brazilian Institute of Public Opinion and Statistics (IBOPE) published a report in 2015 indicating that over $70 \%$ of Brazilians access social media while watching television. ${ }^{22}$ This particular collective behavior illustrates how monumental the SNS engagement rate is and how new media practices affect and deeply transform the experience in consuming older forms of media—such as television

${ }^{18}$ La Nueva Revolucion Digital. Publication. Unidad de Innovación y Nuevas Tecnologías de la División de Desarrollo Productivo y Empresarial, Comisión Económica para América Latina y el Caribe. Santiago: United Nations, 2016.

${ }^{19}$ Fenez, Marcel, and Estela Vieira. Brazil: Leading the Digital Media Revolution in Latin America. Report. PricewaterhouseCoopers . 2014. Accessed February 26, 2017.

http://www.pwc.com/gx/en/global-entertainment-media-outlook/assets/brazil-summary.pdf.

${ }^{20}$ Mesquita, Bruna. " $90 \%$ dos jovens brasileiros possuem pelo menos um perfil nas redes sociais | EXAME.com - Negócios, economia, tecnologia e carreira.” Exame. July 29, 2015. Accessed February 26, 2017. http://exame.abril.com.br/tecnologia/90-dos-jovens-brasileiros-possuem-pelo-menos-um-perfilproprio-em-rede-social.

${ }^{21}$ Chao, Loretta. "Brazil: The Social Media Capital of the Universe." The Wall Street Journal. February 04, 2013. Accessed May 15, 2017. https://www.wsj.com/articles/SB10001424127887323301104578257950857891898.

22 " $88 \%$ dos internautas brasileiros assistem TV e navegam na internet ao mesmo tempo." IBOPE Brasil. Accessed May 15, 2017. http://www.ibope.com.br/pt-br/noticias/Paginas/88-dos-internautas-brasileirosassistem-TV-e-navegam-na-internet-ao-mesmo-tempo-.aspx. 
or newspaper. As the ICT development continues to shape the development Brazil's media landscape, youth have more opportunities to occupy online spaces with media messages that potentially can impact matters in the public sphere-or at least provoke discussions that otherwise would not be voiced out by traditional media.

In Brazil's new media landscape, the rise of a social media culture was deeply shaped by Orkut, a Google social network platform, between 2004 and 2010, during a critical moment for the ICT development in the country. Given the success of the Orkut in the country, the Portuguese language became the most popular language in the platform. Moreover, Orkut has played an important role in the lives of people who currently are savvy users of other popular social media outlets such as Facebook and Twitter. In his discussions on the democratic history of Brazil, Bryan McCann indicates that there are three rules governing the circulation of Brazil's cultural marketplace, and the first one is what he regards as 'the Orkut rule.' McCann observes that the Orkut Rule holds that, wherever possible, "Brazilians will avail themselves of the possibilities of digital media to create subcultural niches and cross-cultural networks in ways that defy traditional hierarchies and the existing cultural canon."23 Based on the Orkut legacy and McCann's discussion, I believe that the increasing consumption and appropriation of new media in Brazil may represent an opportunity for young people to participate in public discussions even if it is via humor.

Furthermore, with the government support in reducing the digital divide among the country's economically unequal population, Brazilians increasingly generate new

\footnotetext{
${ }^{23}$ McCann, Bryan. The Throes of Democracy: Brazil since 1989. Global History of the Present. Halifax, Nova Scotia: London; New York: New York: Fernwood Pub.; Zed Books; Distributed in the USA Exclusively by Palgrave Macmillan, 2008, p. 131.
} 
opportunities through new media for social interaction, entertainment, consumption, production, and information-gathering. Existing studies on the cultural practices of social media use in Brazil have focused on various issues such as the relationship between civic protests and the usage of Facebook and Twitter. However, very few focused on the youth's appropriation of technology for civic engagement. To help clarify this existing gap, I rely on Heather Horst's discussion of three key cultural aspects that I considered highly useful for the thesis. Essentially, Horst's work describes how the juxtaposition of the broad themes of digital inclusion, free culture, and networked sociality captures the new media landscape in Brazil. ${ }^{24}$ While Horst's ideas provide indispensable context for this research, it is also important to note that these three main themes do not seem to be unique to the Brazilian case. Yet, I agree that they represent a significant part of the framework required for understanding new media practices and, ultimately, how Brazilians engage with the political discourse via memes.

Digital inclusion, free culture, and networked sociality are three factors that help facilitate youth engagement in Brazil's digital era. According to Horst, digital inclusion is important to increase access and consumption of new media among marginalized populations, which can be achieved through public policies and incentives on democratizing the Internet access for everyone. For example, as a way to support the digital expansion across the country, the Brazilian government developed programs that specifically targeted youth in low-income areas, with the goal of encouraging the computer use and enhancing skills while heavily promoting open source software across

\footnotetext{
${ }^{24}$ Horst, Heather A. "Free, Social, and Inclusive: Appropriation and Resistance of New Media Technologies in Brazil." International Journal of Communication 5 (2011): 437-62.
} 
schools and universities. Projects of this sort provided an important foundation to

understand the 'free culture' that Horst associates with Internet access and later on the usage of SNS. In a possible association between such 'free culture' with Brazil's chaotic democratic past, McCann observes:

Brazilians actively engaged in this expansion describe it as a democratization of culture and as a digital realization of the aspirations for greater equality in the postdictatorship period that have been achieved only partially in other spheres. High-ranking civil servants such as Minister of Culture Gilberto Gil have made digital democratization a major objective, crafting various policies to further the "digital inclusion" of Brazil's poor and working-class citizens. ${ }^{25}$

It is largely in regards to such free culture that SNS played an influential role in giving a voice to the vulnerable citizens whose realities were seldom represented in traditional media such as television or elitist newspapers. Ordinarily, a television show would mainly reproduce the image of an idealized Brazil, one which only the elite could have access to-from Bossa Nova to the beaches of Rio de Janeiro. In this way, the democratization of the Internet or what McCann calls the "democratization of culture as a digital realization" played a significant role in connecting the disparate realities of a generation of residents from Brazil's peripheries to the rest of the country. Such democratization enabled them not only to voice their concerns and worldviews but also create and circulate media content that relates to their unique realities (e.g. music genres such as Funk).

If the state's policy of digital inclusion and subsequent formation of free culture explains the political and economic context of Internet culture in Brazil, the concept of

\footnotetext{
${ }^{25}$ McCann, Bryan. The Throes of Democracy: Brazil since 1989. Global History of the Present. Halifax, Nova Scotia: London; New York: New York: Fernwood Pub.; Zed Books; Distributed in the USA Exclusively by Palgrave Macmillan, 2008, p. 132.
} 
"networked sociality" adequately addresses the behavioral dimension of this ICT development amongst individuals. In fact, networked sociality helps conceptualize the notion of how the hyper-social dimension of Brazilian culture plays out in online engagement, including the frequent intertextual messages between individuals, government, and popular culture. The term network sociality does not necessarily represent "the sense of belonging" to the community; rather, it represents, as Andrea Wittle argues, a new emerging model of sociality "which are not 'narrational' but informational. ${ }^{26}$ Wittle argues that network sociality is not based on mutual experience or common history, but primarily on an exchange of data and on 'catching up. ${ }^{27}$

To a large extent, the development of Brazil's new media landscape paved the way for a networked sociality that opened a universe of media production, messages, and consumption among youth, which, in turn, has expanded the way social capital is understood and practiced within a network of trust and cultural similarities. ${ }^{28}$ Accordingly, "social capital is a way to describe an aspect of human behavior that had a rich history long before the internet came along, but is now an important part of the socializing that online media make possible." ${ }^{29}$ In my view, this definition may include the potential held by a single person as well as the collective potentials that can be deployed together by ordinary citizens for the benefit of a group or community.

\footnotetext{
${ }^{26}$ Wittel, Andreas. "Toward a Network Sociality.” Theory Culture and Society 18, no. 6 (2001): 51-76.

${ }^{27}$ In this sense, network sociality consists of fleeting and transient, yet iterative social relations; of ephemeral but intense encounters. Wittle also acknowledges that the concept of network sociality is incomplete partially because of the uncertainties around the impact of social media in society in the long run.

${ }^{28}$ Horst, Heather A. "Free, Social, and Inclusive: Appropriation and Resistance of New Media Technologies in Brazil.” International Journal of Communication 5 (2011): 453.

${ }^{29}$ Rheingold, Howard. Net Smart: How to Thrive Online. Cambridge, MA: MIT Press, 2012, p. 217.
} 
Particularly in the case of Brazil, this also has a profound impact on the cultural relevance of what it means to consume, appropriate, and assign symbolic meaning to a new media practice. In association with humor, such networked sociality is intrinsically pertinent in Brazil's new media landscape because it helps us better comprehend how the culture of Internet memes reflects an engaging dialogue with issues in the public sphere. 


\section{Chapter 3: Internet Memes: Artifacts of Participatory Culture}

Despite the frequent negative connotations associated with the term, I argue that it is imperative to consider memes as artifacts of participatory digital culture. This is because memes, aside from their hyperbolic nature as a media text, showcase creative ways of thinking about a situation, and that process is highly conditioned by the cultural niches and media references of where it gains symbolic meaning. A meme in the United States, for example, will rarely incorporate elements from a Brazilian celebrity. A Hollywood celebrity, on the other hand, can easily be found in memes in Brazil. In addition to reflecting the symbolic references of their place of origins or the interpersonal relationships associated with them, one can also argue that memes reflect the current media flow of content usually dominated by English-speaking and American popular cultural references.

While they may share similarities in other places, memes in Brazil exemplify the core notion of Orkut rule because they allow young people to voice out their views by creating and sharing content that defies the status quo, satirizes a situation or praises their own and unique realities — often marginalized and ignored by traditional media. That is to imply that, in order to critically analyze meme culture in the Brazilian context, it is imperative to understand its relation to the Orkut rule, since it arguably paved the way for how Brazilians behave in online communities, with special attention to those who until recently had zero or limited access to new media technologies. After all, it was the Orkut platform that built the first successful cyberspace ${ }^{30}$ in Brazil, which

\footnotetext{
${ }^{30}$ Howard Rheingold defines Cyberspace as the conceptual space where words, human relationships, data, wealth, and power are manifested by people using computer-mediated communications (CMC), while virtual community refers to the cultural aggregation between people within a cyberspace.
} 
is captured in the idea that "being on the Internet meant being on Orkut." ${ }^{31}$ Although the Orkut platform was not exclusive to Brazil's new media landscape, it allowed Brazilians to see themselves, for the first time in such popularity, as part of a wellspread online community within the country's cultural universe. In such space, users could engage with each other and exchange information on a variety of topics such as soccer, telenovela, religion, and samba. Many argue that the success of Orkut in Brazil was deeply related to the spread of $\mathrm{LAN}^{32}$ houses across the country alongside the government effort in promoting the idea of "computers for all." 33 In fact, one did not need to have high-speed Internet access at home to be part of online communities since the LAN houses were accessible and cheap (around 50 cents to 1 dollar per hour). The initial steps for the democratization of the Internet justify the fact that by early 2006 over $60 \%$ of Orkut users were Brazilians, while less than 15 percent of the users were from the United States. ${ }^{34}$

Before the emergence of new media in Brazil, mass media outlets such as television — and, consequently, telenovela-were certainly at the forefront in shaping culture and public opinion, considering the centrality of the TV system as I

\footnotetext{
${ }^{31}$ Recuero, Raquel. "Social Media in South America: Orkut \& Brazil." DML Central. June 08, 2016. Accessed April 27, 2017. https://dmlcentral.net/social-media-in-south-america-orkut-brazil/.

${ }^{32}$ LAN stands for "Local Area Network," which refers to computers assembled together to allow people to play multi-player games. Popular in Asia, in places like Korea, and previously existing only in the rich neighborhoods of Brazil, they have now become a phenomenon proliferating in poor communities, especially the favelas. (Ronaldo Lemos).

${ }^{33}$ Lemos, Ronaldo, and Paula Martini. LAN Houses: A New Wave of Digital Inclusion in Brazil. Report. Center for Technology and Society, Fundação Getulio Vargas Law School. Accessed March 29, 2017. http://publius.cc/lan_houses_new_wave_digital_inclusion_brazil/091509.

${ }^{34}$ McCann, Bryan. The Throes of Democracy: Brazil since 1989. Global History of the Present. Halifax, Nova Scotia: London; New York: New York: Fernwood Pub.; Zed Books; Distributed in the USA Exclusively by Palgrave Macmillan, 2008, p. 131.
} 
demonstrated in Chapter 2. In youth digital culture, nevertheless, it has been discussed that memes partake in a shared experience of a spontaneous civic participation that is not necessarily conditioned by mass media. Conversely, memes receive contributions of online participants, often forming waves of collective opinions that flourishes beyond social media. ${ }^{35}$ The Orkut's legacy among Brazilian youth demonstrates that a hypersocial culture played a pivotal driving force in ICT and computer-mediated communication (CMC) developments, which continues to impact how youth access and appropriate other SNS, such as Facebook and Twitter. As I introduced in Chapter 1, the Brazilian case also suggests that youth may use memes as a paratext for participation. That is not to say that such type of participation completely fulfills the civic agency often expected from those interested in participating in a democratic society, but it certainly represents a form of participation.

\section{Defining Internet Memes}

Before delving into the cultural relevance of memes in the political context, it is important to clarify the confusions around the term. In fact, the term meme has led to disagreements about the way scholars and society at large discuss ideas that are replicated both online and offline. Although used by many when referring to splashes of Internet humor, the word meme emerged long before the Internet was created. The evolutionary biologist Richard Dawkins coined the term 'meme' to convey the idea of a unit of cultural transmission usually performed through imitation. In fact, 'mimeme'

\footnotetext{
${ }^{35}$ Freire, Fernanda. Uma Breve Reflexão Sobre Memes Políticos, Humor e Conversação Cotidiana Informal. Universidade Federal de Minas Gerais. Opinião Pública. August 2016. Accessed April 1, 2017. http://opiniaopublica.ufmg.br/site/files/artigo/3-Fernanda-Freire-REV.pdf.
} 
comes from a Greek root, but Dawkins' intention was to simplify it to 'meme' so that it sounded like 'gene,' considering that his idea was based on the theory that cultural transmission is analogous to genetic transmission. ${ }^{36}$ According to Dawkins, memes originate within what he calls "the soup of human culture," an allusion to the conditions that may potentially have enabled complex chemicals to become self-replicator molecules in the oceans during the early phase of the Earth. ${ }^{37}$ Memes, within this broader definition, includes anything that can be replicated in culture such as big ideas, catchphrases, tunes, clothes fashions, cultural artifacts, language, art, technology, etc. In this way, computers in which memes live are like human brains and should be regarded as living structures, not just metaphorically but technically. ${ }^{38}$ In extrapolating his ideas, it is possible to affirm that memes are part of what distinguishes humans as unique in replicating messages and enhancing "the soup of human culture."

However, for the purpose of this research, I use the term Internet meme specifically in relation to the digital culture; thus, I treat it as a postmodern folklore, where images and short texts reflect cultural symbols within a saturated intercultural universe of media possibilities. Limor Shifman defines Internet memes as (i) a group of digital items sharing common characteristics of content, form, and/or stance, which (ii)

\footnotetext{
${ }^{36}$ Dawkins, Richard. The Selfish Gene. New ed. Oxford; New York: Oxford University Press, 1989, p. 189.

${ }^{37}$ Ibid., 192.

${ }^{38}$ In considering memes as cultural units, Dawkins implies that humans are built as gene machines and cultured as meme machines. However, back in the 1970s, when Dawkins first developed the term, the development of the Internet was in its initial steps, and therefore the relationship between new and digital media was far beyond what we experience in today's globally connected reality. Although memes still may exist in human brains, they assume other forms that are only possible through the rapid ICT development. Furthermore, Dawkins ideas on memes are well criticized by many academics who consider the idea of self-replicating to be quite deterministic, and even the study of it to be pseudoscience.
} 
were created with awareness of each other, and (iii) were circulated, imitated and/or

transformed via the internet by many users. ${ }^{39}$ Shifman's discussions show that Internetbased political memes fulfill three interwoven functions: memes as forms of persuasion or political advocacy, memes as grassroots action, and memes as forms of expression and public discussion. ${ }^{40}$ As in many countries in the world, the spread of memes in Brazil frequently occurs in platforms such as Facebook and Twitter, but not exclusively. Consequently, the memes I analyze next came from these platforms, given their popularity and cultural relevance in Brazil's online spaces.

\section{Cultural Relevance of Facebook and Twitter in Brazil's Online Spaces}

Similar to the extinct Orkut platform, the remarkable influence of Facebook and Twitter on Brazilian culture gave a space for young Brazilians to not only consume information but also to create and circulate content. Outside Brazil, these two platforms also gave voice to youth across several socioeconomic realities, allowing for new modes of political expression. In South Korea, for example, the high penetration of the Internet created a civic culture that has enabled the mobilization of young people in public participation through the use of diverse new media technologies such as the "Candlelight Protests" in 2008, about four years before Facebook dominated Brazil's digital market. The use and appropriation of new media around the notion of youth participation, when facing problems in the public sphere, enabled the rise of a form of e-politics that started to emerge long before social media became prominent in Brazil.

\footnotetext{
${ }^{39}$ Shifman, Limor. Memes in Digital Culture. MIT Press Essential Knowledge Series. Cambridge, Massachusetts: MIT Press, 2014, p. 41.

${ }^{40}$ Ibid., passim.
} 
In a similar fashion to the Brazilian landscape, Korean youth started to use new media to challenge the monolithic and centralized mode of the dominant media, demonstrating the nuances in which "young people tend to combine participation in social and political affairs with play, parody, humor, wit, and caricature to express their feelings and opinions rather than direct criticism. ${ }^{, 41}$ The Korean case provides us context to better apprehend how the democratization of the Internet followed by the high penetration of Facebook and Twitter within Brazil's new media landscape are continually intensifying participatory culture. Therefore, such configuration grants youth the power to use humor while circulating digital memes as a form of online civic engagement.

In Brazil, there are about one million active users per month on Facebook, meaning that eight out of ten Brazilians are connected to the platform. ${ }^{42}$ Despite being the world's most accessed social media platform, it was not until 2012 that Facebook overcame Orkut's popularity in the country. ${ }^{43}$ Twitter on the other hand, claims its success in Brazil largely due to the culture of television in Brazil. This is because television content is often the most talked about subject among Twitter users. ${ }^{44}$ Such online culture emerged around the cultural practice of being with family while watching

\footnotetext{
${ }^{41}$ Ok, HyeRyoung. "New Media Practices in Korea." International Journal of Communication 5 (2011): $320-48$.

${ }^{42}$ Facebook \#CPBR9. Performed by Ime Archibong. January 29, 2016. Accessed March 29, 2017. https://www.youtube.com/watch?v=OSADQZ9XOwA.

${ }^{43}$ A 2012 report published by Socialbakers - the same year that Facebook became the most popular SNS in Brazil—revealed that Brazilian pages were the most active ones with the highest number of posts per month than any other country on Facebook.

${ }^{44}$ Twitter is one of the top social media worldwide with about 320 million active users monthly. According to Folha de S. Paulo, despite the economic crisis, the company's revenue grew about $30 \%$ in 2016 in Brazil, nearly twice as much as the global average. Research also suggests that Portuguese is among the most popular languages on Twitter. Moreover, data also show that $97 \%$ of Brazilian users watch television every day and $50 \%$ access their phones while doing so.
} 
telenovela after a day at work or school. ${ }^{45}$ James Green argues the Twitter success in Brazil is tied intimately to "the history of the country's rise from the shadow of authoritarianism to its newfound status as a budding global power." ${ }^{46}$ Upon the end of the military dictatorship in 1985 , media conglomerates helped unite the country's emerging civil society. The rise of the middle class in the early 21 st century alongside the development in ICT enabled a significant uptake of Twitter.

The popularity of Facebook and Twitter, potentially continuing the legacy the Orkut rule, has played a significant role in offering an online space for production, consumption, and circulation of cultural commodities. It was in both platforms that the memes became popular amongst most Internet users. Prior to the impeachment case in 2016, there had been other instances where SNS users modified images with catchphrases to satirize a situation, a group of people, or a sociocultural behavior. For example, Brazilian Internet users have engaged in what has been regarded across social media as "World War of Memes" against Portuguese, Argentinean, and Spanish Internet users in $2016 .^{47}$

\footnotetext{
45 “Twitter divulga infográfico com perfil do usuário brasileiro.” Aba.com.br. November 24, 2015. Accessed March 30, 2017. http://www.aba.com.br/canais/midia/artigos/twitter-divulga-infografico-comperfil-do-usuario-brasileiro.

${ }^{46}$ Fastenberg, Dan. "Why Is Twitter So Popular in Brazil?" Time. October 20, 2010. Accessed March 30, 2017. http://content.time.com/time/world/article/0,8599,2026442,00.html.

47 Sputnik. "Weird War of Memes Bursts Out Between Brazil and Portugal." Sputnik International Breaking News \& Analysis - Radio, Photos, Videos, Infographics. June 18, 2016. Accessed May 14, 2017. https://sputniknews.com/world/201606181041569190-brazil-portugal-war-memes/.
} 
Each one of these events generated hashtags on Twitter that became global trend topics, obtaining the attention of national and international media outlets such as the online platform 9gag. It was also the occasion through which Brazilians self-proclaimed themselves as "the best meme creators" in the Internet. Moreover, the fact that users

Figure 1: Meme from the III World War of Memes

\#TerceiraGuerraMemeal (a)

This meme is a satire which illustrates Brazilians Internet users engaging in a type of online warfare against Portugal, Spain, and Argentina in 2016.

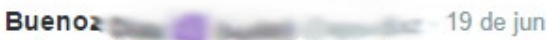

sobre a \#TerceiraGuerraMemeal... que venha a \#QuartaGuerraMemeal !

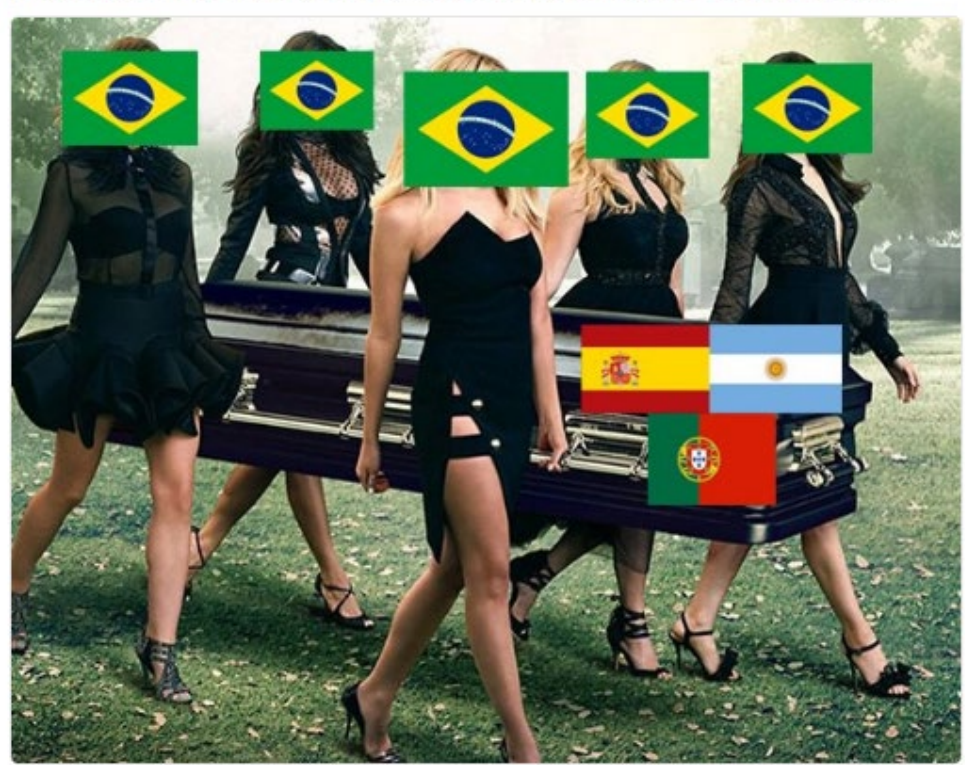




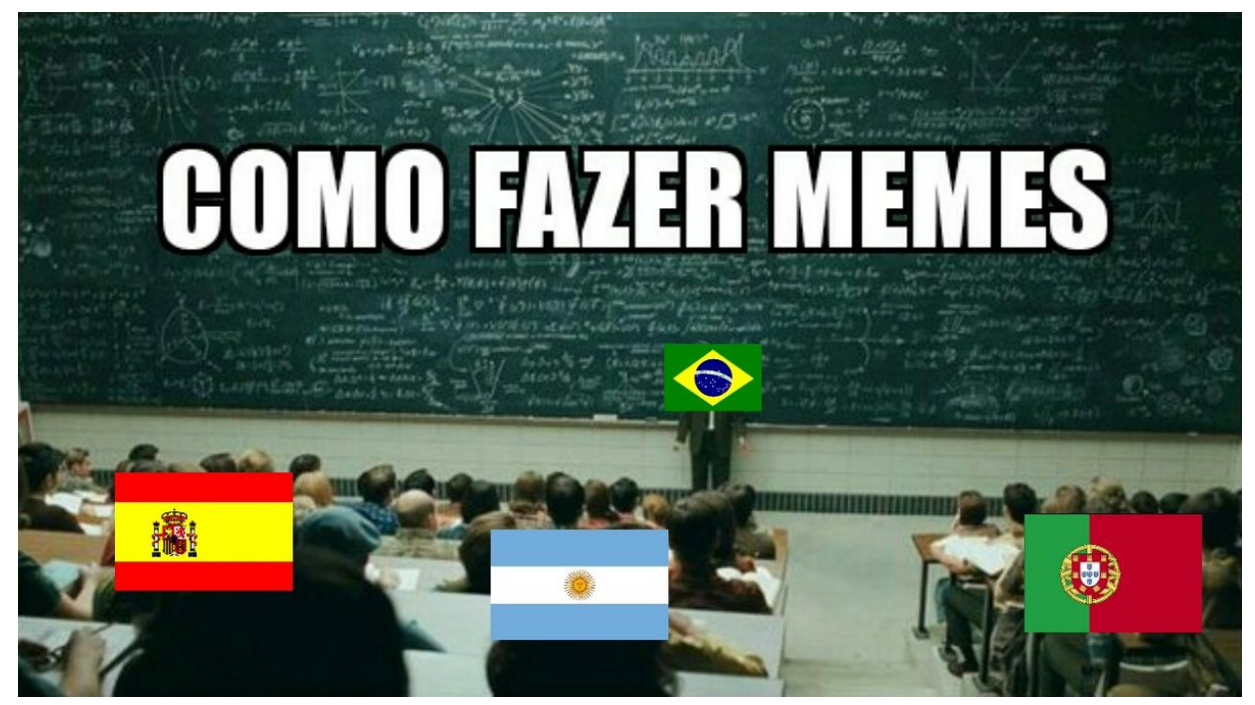

Figure 2: Meme from the III World War of Memes

\#TerceiraGuerraMemeal (b)

The quote in the meme translates for "How to Make Memes." The meme

summarizes the Internet battles that characterized what Brazilians

considered as the "World War of Memes" against Spain, Argentina and

Portugal.

from other countries appropriated and modified Brazilian memes ended up occupying

SNS with silly splashes of visual humor coupled with short texts.

In addition to such transnational meme communication via SNS, Brazilians have also responded to potential threats from the so-called Islamic State (ISIS) using humor, turning YouTube and TV celebrities into national heroes through the production of memes. Other events and trends such as the Olympic games and the launch of the smartphone game Pokémon Go have also widely inspired youth to create memes online and share with their networks. These few examples alone illustrate the creative power and level of participation through which Brazilian youth perform on social media when discussing unrelated diverse topics—-from popular culture to sports or politics. 
6) View translation

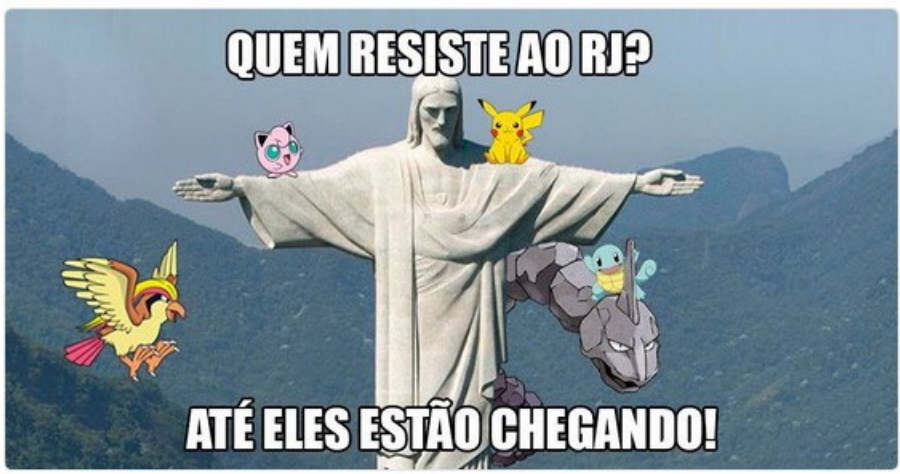

Figure 3: Christ the Redeemer and Pokémon Go \#Rio2016

The Government of the State of Rio de Janeiro used a meme to associate the popularity around the launch of Pokémon GO with the 2016 Olympic Games.

\section{já pensou o estado islâmico tenta ataca o rio nas olimpiadas mas o cristo redentor vira um megazord e salva td mundo}

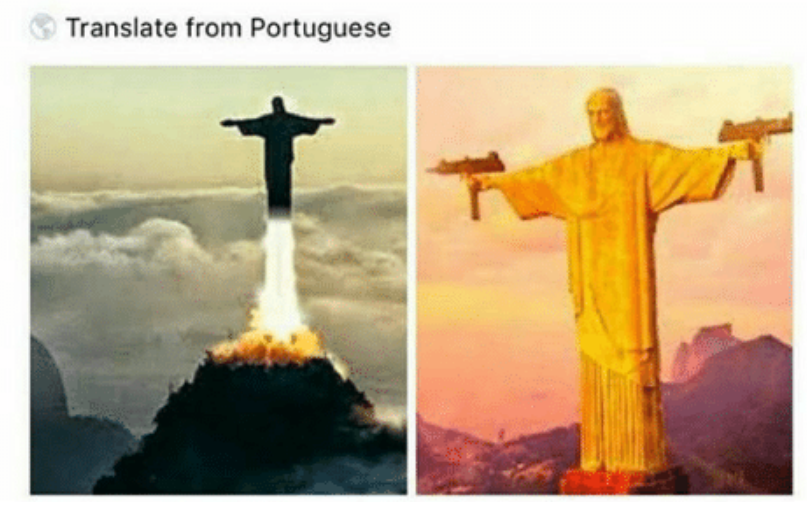

Figure 4: Christ the Redeemer, the Islamic State (ISIS), and the Olympic Games

The text along the picture reads the following: "Imagine if the Islamic State attempted to attack Rio during the Olympic Games but the Christ the Redeemer becomes a Megazord and saves everybody." 


\section{Chapter 4: Case Study: The 2016 Impeachment Through the Lens of}

\section{Memes}

Since the democratic movement in the 1980s, Brazil has performed two impeachment proceedings - one in 1992 and the most recent in 2016. Accordingly, the level of youth engagement of each case largely reflected the media landscape of their times. While there was not such a thing as democratized SNS in the early 1990s, its prominence in 2016 opened up new ways of engaging with the political discourse. Provided that perspective, the platforms through which youth reacted to the impeachment of Dilma Rousseff were substantially different from the one previous generation of youth performed against Fernando Collor de Mello in 1992 - the first impeachment case in Latin America. Not only were the motives behind the movements themselves substantially different, but so were the media technologies available. One could even argue that the Internet and SNS, for instance, have certainly increased information access of those from marginalized communities as I showed in Chapters 1 and 2.

Unlike the 1992 impeachment, the social mobilization of 2016 relied on many forms of from ICT-related plaftforms, which expanded the means of youth communication across different regions, educational, and socioeconomic levels. As matter of fact, SNS played an important role in allowing youth to organize protests across Brazil. For example, the protests of the $13^{\text {th }}$ of March, against Dilma Rousseff and her government, became the largest political manifestation in the country's history, with the famous saying $O$ Gigante Acordou, or 'the giant awoke', becoming the motto for the national protests. "Brazilians no longer want to accept the corruption within 
the Brazilian government, but rather they want to become informed, educate others, and show that, as a people, Brazilians are aware and want to change the corruption that has been running rampant in the government." ${ }^{\prime 8}$

During the impeachment process of Brazil's first female president in 2016, Brazilian youth utilized Facebook and Twitter as a vehicle to share an impressive number of Internet memes. In this controversial context dominated by popular frustration and staggering economic recession, Internet memes generally either criticized the impeachment, supported it, or ridiculed the controversies around the proceedings. When in relation to the previous protests that took over the streets in the early stages of Rousseff's administration, the underlying motives of having memes as a gateway for participation clearly mirror Rebecca Pike's argument from the 2013 protests:

What has given Brazilians so much pride is not just demanding a less corrupt Brazil. Brazilian pride has also come from the fact that they are mobilizing as united civilians rather than at the prompting of defined leaders. Brazilians who have taken to the streets do not want Brazil to be known as just a country that is defined by soccer, Carnival, and tiny bikinis. The protesters are now demonstrating to create a country that would have more hospitals and medical services, a higher quality education system, and adequate infrastructure, amongst a myriad of other services to help Brazil further develop. ${ }^{49}$

Interestingly enough, however, Internet memes of the impeachment process seem to combine these two central aspects: the humor that is often associated with Brasilidade (the Brazilian way of making sense of reality), as well as the growing

\footnotetext{
${ }^{48}$ Pike, Rebecca P. ''O Gigante Acordou': Brazilian National Protests for Policy Reforms and Why They Matter.” Georgetown Journal of International Affairs. June 29, 2013. Accessed April 24, 2018. https://www.georgetownjournalofinternationalaffairs.org/online-edition/o-gigante-acordou-braziliannational-protests-for-policy-reforms-and-why-they-matter-by-rebecca-p-pike.

${ }^{49}$ Ibid., passim.
} 
frustration with politics. More specifically, there were three special instances that the circulation of Internet memes around the impeachment in online spaces grabbed the attention of country's largest media outlets: April $17^{\text {th }}$, May $12^{\text {th }}$, and September $31^{\text {st }}$ of 2016. In the following paragraphs, I frame my analysis of memes around these three dates, which I later refer as $1^{\text {st }}, 2^{\text {nd }}$, and $3^{\text {rd }}$ memetic waves respectively.

As asserted by various media scholars in other instances, such as during the Arab Spring in 2010, the increased level of youth participation online holds power in impacting activities in the public sphere. This is often cited as such when a group of students mobilizes an offline protest using SNS. However, in the case of Internet memes, it is seemingly challenging to properly contextualize their messages in relation to both culture and politics given its recent emergence as a youth media practice as well as the many possible layers of symbolisms they carry. Beyond the realm of SNS platforms such as Facebook and Twitter, the youth creativity and audacity in creating and circulating memetic content during the impeachment also captivated the attention of traditional media outlets such as $O$ Globo and $O$ Estado de S. Paulo, both regarded as two of the three most influential daily news vehicles in Brazil. Furthermore, multiple other blogs covered the popular fascination with memes during this period, often associating their creation and spread with Twitter hashtags such as \#impeachmentday, \#tchauqueridaday, \#golpistaday, and \#naovaitergolpe. These hashtags functioned as keywords that guided online battle between social media users. From the side that support Rousseff on Facebook, many memes first appeared in popular pages such as Dilma Bolada, Quebrando o Tabu, Otariano, Menes de Esquerda, Ajuda o Povo de Humanas a Fazer Miçangas, among others. 


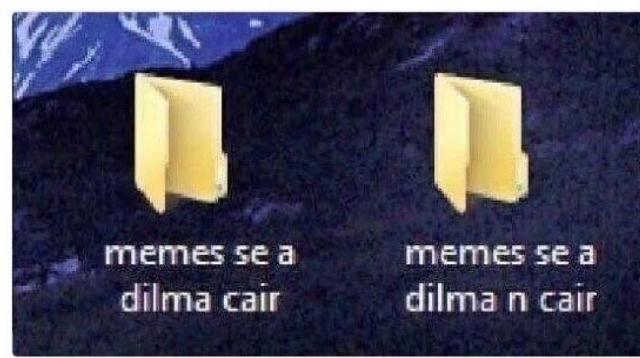

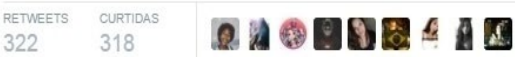

15:08 - 17 de abr de 2016

Figure 5: Organizing Memes in Folders \#ImpeachmentDay

This meme shows that an online user created two folders, which suggests that

Internet users will create and circulate memes regardless of the outcome of the impeachment of Dilma Rousseff. Memes, in this case, will be created and circulated regardless of the outcome.

To some degree, both Twitter hashtags and Facebook pages reflected the country's division between left and right wings and the difficulties in assessing what a contemporary democracy should look like. Following a global tendency, the high level of participatory culture in each event also exemplified the relevance of how memes instigate creativity even if it denotes a trivial discussion. In fact, Google Trends ${ }^{50}$ data reveal that out of these three important dates, the period of the first date from April $17^{\text {th }}$ to April $23^{\text {rd }}$ of 2016 was when the internet search for "memes impeachment" has soared to its highest levels of popularity in Brazil's Internet history, having the southeast region as the most active one in researching the terms. Regardless, there are

\footnotetext{
${ }^{50}$ Google Trends is an online search tool that allows the user to see how often specific keywords, subjects and phrases have been queried over a specific period of time. Google Trends works by analyzing a portion of Google searches to compute how many searches have been done for the terms entered, relative to the total number of searches done on Google over the same time.

(http://whatis.techtarget.com/definition/Google-Trends)
} 
many challenges in attempting to categorize memes since they constantly change after establishing a connection of meanings within a complex universe of contexts.

To better demonstrate how this division played out in the unveiling of the discourse around the impeachment process, I attempt to describe trends found in memes from three pivotal moments of the impeachment process that were reflected in other traditional media, as I said in the beginning of the chapter. A timeline of the events go as the following: on April $17^{\text {th }}$, more than two-thirds of lawmakers in the Brazilian parliament's lower house voted to validate the impeachment process against Rousseff; on May $9^{\text {th }}$ and $12^{\text {th }}$, the first voting session was canceled, but after a few days Brazil's senate voted 55-22 and suspended Rousseff; and on August 31st, the senate voted 61-20 and impeached Brazil's first female president.

To summarize, these three dates reflected the movement of the impeachment trial from the parliament's lower house to the senate within a period of about five months. This is not intended to provide a strict division, but rather to find the main trends observed in specific periods when the political discussions became the center of attention both in online and offline spaces-from blogs to newspapers. The periodization is to showcase how the meme discussion has changed over time, including its adaptation, appropriation, and rapid response to media texts outside the impeachment case. For close analysis, I have selected memes from these three main dates that have been observed across Facebook pages and usually associated with popular hashtags both in favor and against the impeachment. Considering the nature of memes as being messages created and shared anonymously, it is difficult to trace the origin or creator of 
a specific memes, but I focus on a series of most popular memes that have been shared both on Twitter and Facebook.

\section{$1^{\text {st }}$ Memetic Wave: April $17^{\text {th }}$}

The month of April 2016 has a historical relevance in Brazilian politics because it was when the Congress first officially voted in favor of the impeachment against Rousseff. This voting process occurred under popular pressure of uncountable series of protests that took place all over Brazil since her re-election in 2014. The uncertainty about the future of the country's economy as well as the scandals of corruption from the president's Worker's Party (Partido dos Trabalhadores - PT) intensified the political debate, despite the controversies of the liability of the impeachment. Within the meme context, the $17^{\text {th }}$ of April mostly represented an opportunity to use memes to critique the inconsistencies of the allegations for the impeachment as well as to satirize the rhetoric of the politicians who voted against Rousseff. While TV channels broadcasted the voting session, several memes quickly circulated on Twitter and Facebook. In this occasion, there were memes against and in favor of Rousseff, but there were also memes satirizing the elements of the voting session. For example, figure 6 uses the images of popular celebrities to mock the inconsistencies of the long voting session as well as the arguments broadcasted on television situation by appropriating the cultural imagination. 


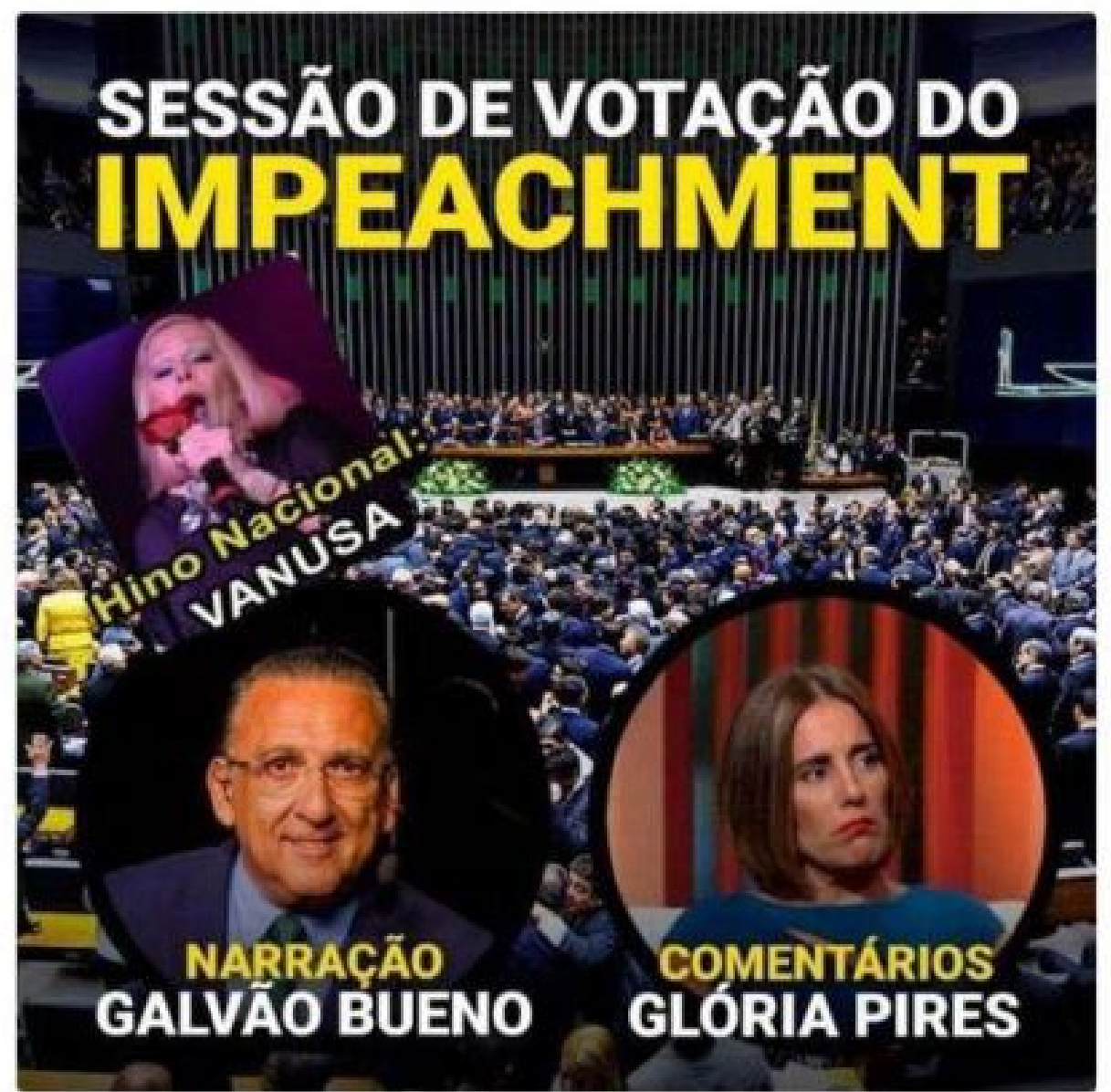

Figure 6: Depiction of Celebrities in the Congress

This meme suggests that the voting session included three public personalities from the television, including a sport reporter, an actress, and a singer. Each one of these celebrities had become memes in past circumstances.

Such memes illustrate an awareness of the youth in critiquing the politicians' arguments in the lower house who voted in favor or against Rousseff. Moreover, these types of memes functioned as a tool to point out the lack of political argumentation and the hypocrisies in the context of political parties and scandals in Brazil appropriating elements of popular culture such as telenovela. 


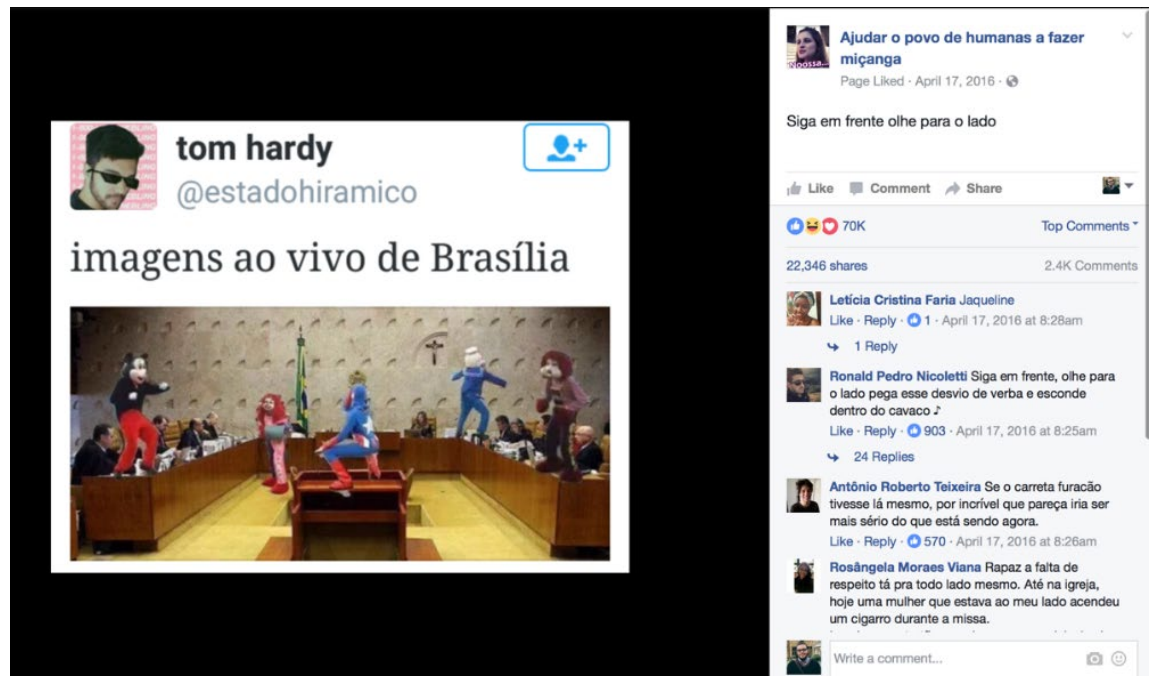

Figure 7: "Live from Brasília" with TV characters

The short text translates for "Live from Brasília." The juxtaposition of

characters in this meme illustrates the collective perception that the impeachment assumed a party- or joke-like nature.

Given the long duration of that particular session at the Congress in Brasilia, the country's capital, many youth shared memes on Facebook pages and Twitter during the voting that featured politicians as characters from familiar popular culture and the

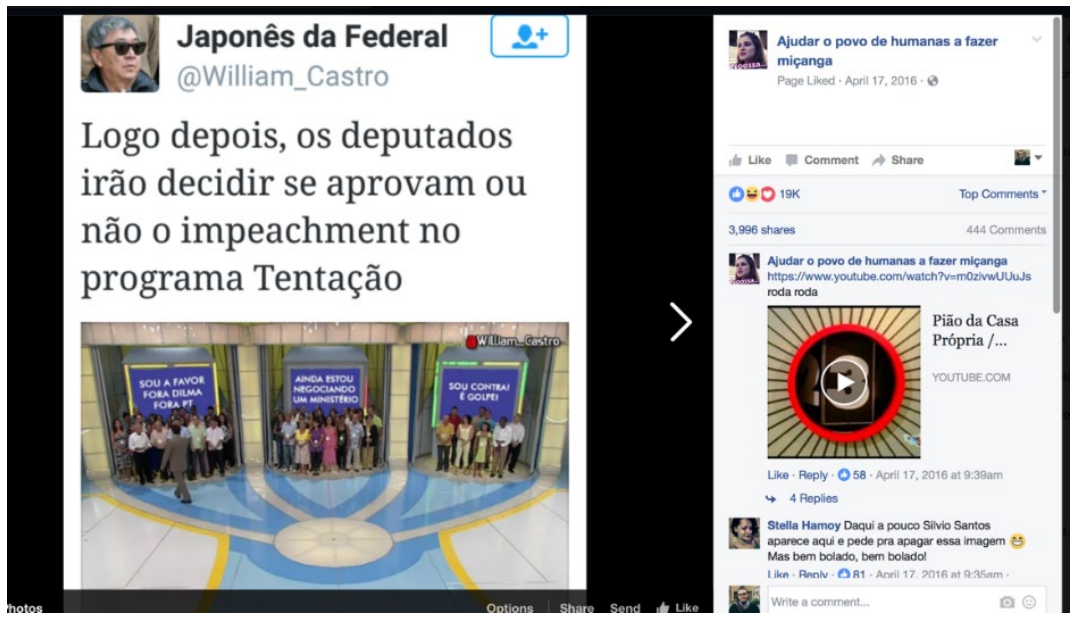

Figure 8: Voting session as a TV show

The meme suggests that the voting process would have been easier if it was structured like a famous TV show from SBT, one of Brazil's most popular TV channels. 


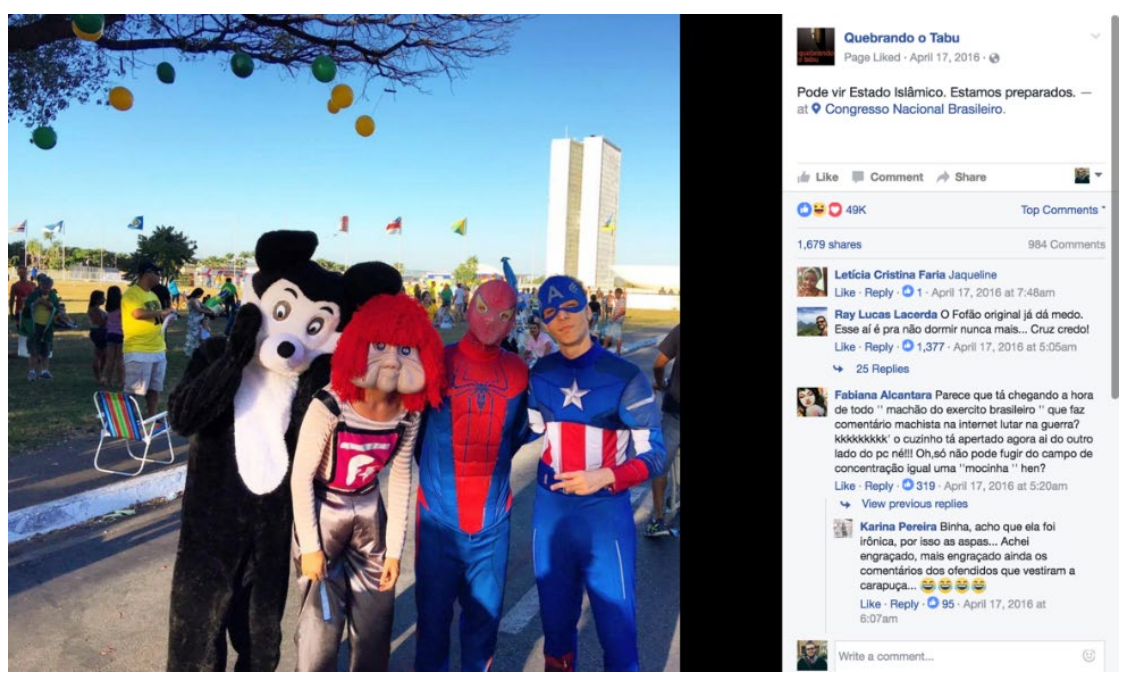

Figure 9: Mickey, Fofão, Spider-Man, Captain America, and the Islamic State (ISIS)

Characters from American media and Brazilian TV. An approximate translation for the caption would say: "Bring it on, ISIS. We are ready."

voting session as a TV show with an unpredictable script (fig. 8). The memes for this specific day explicitly pinpoint the substantial role that TV has played in shaping Brazilian culture and public discourse. On the same day, there were also memes concerning the Islamic State, which may initially be seen as an unrelated event to the impeachment scenario. However, a few days prior to the voting process, Brazilian media outlets reported a potential threat message from ISIS, which empowered Brazilian youth to circulate a series of memes. These memes were able to juxtapose a potential terrorist threat within the impeachment scenario (fig. 9) by mockingly inviting ISIS to attack Brazil's congress in Brasília (fig. 4). 
$2^{\text {nd }}$ Memetic Wave: May $9^{\text {th }}$ and May $12^{\text {th }}$

On May $12^{\text {th }}$, Brazil's Senate voted again and decided to suspend Dilma Rousseff for 180 days. This second round took place because the initial session that had decided to continue the impeachment process against Rousseff on April $17^{\text {th }}$ was canceled. This dramatic change of events inspired SNS users who were against the impeachment to share memes as a way to celebrate Rousseff's victory. Memes of this type usually originated from popular pages such as Dilma Bolada, a fictional Facebook and Twitter character that originated during the 2010 presidential elections as part of a political campaign. Such memes supported Dilma Rousseff by creating a brave fictional persona that is humorous, brash, and with and motherly characteristics. The combination of such features allowed users to make associations of the image of Dilma with "Mother of Brazilians," as the page refers. Upon the cancellation of the April $17^{\text {th }}$ session, memes that featured Rousseff's photoshoped images with lyrics of Beyoncé's "Bitc*, I'm back by popular demand," drew great attention on social media.

Typically, these memes represented a narrative in which Dilma had chances of overturning the situation and, ultimately, commemorating the victory over the impeachment with derision. However, a few days later, the lower house second vote led to the decision to suspend Rousseff again. The suspension of the former president created a new wave of memes on Facebook and Twitter that used humor to criticize not only Rousseff as president but also as a person and a woman as figures in the next page illustrate. 


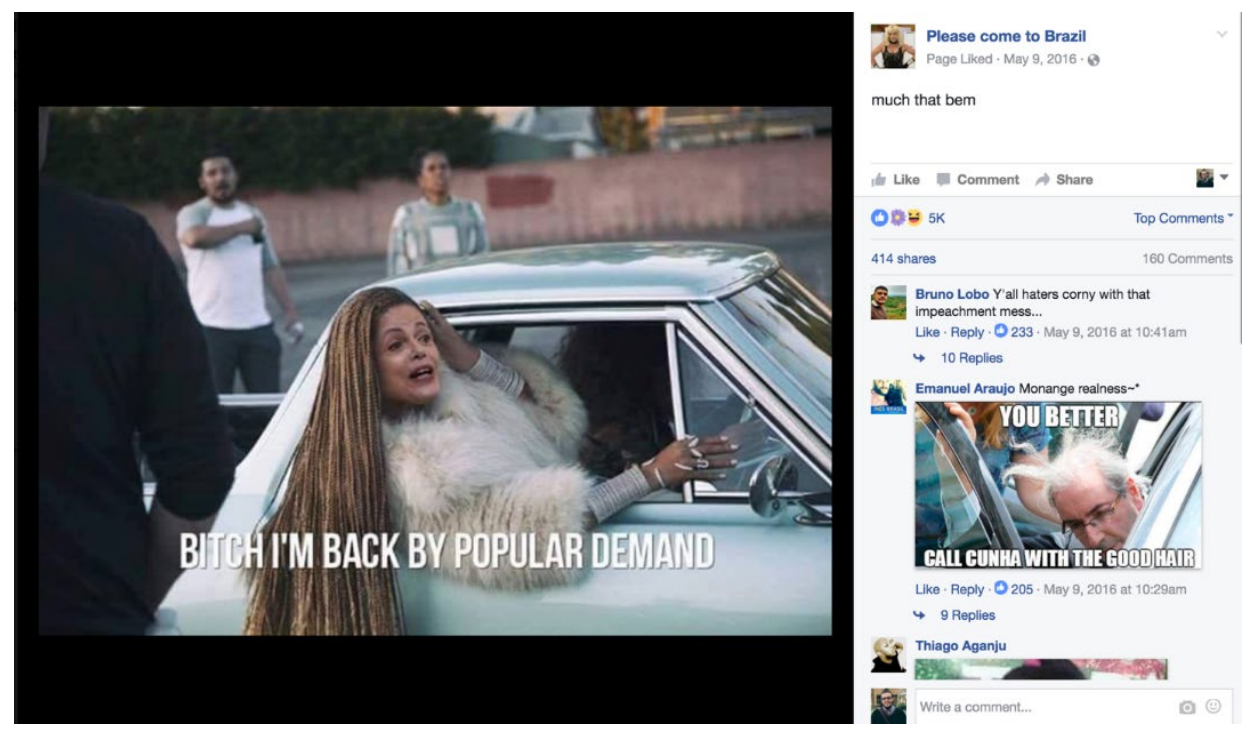

Figure 10: Dilma Rousseff and Beyoncé's Formation.

The meme associates the image of Dilma Rousseff with Beyoncé by using a photoshoped image. There is also an association with the language element present in her song "Formation," which was launched in 2016.

The cancellation of the initial decision to impeach Dilma was arguably factual due to flaws in the process. The two most remarkable content for memes observed during this second wave reflect the uncertainties around the legitimacy of the democratic process in the face of a crisis and the resulting collective image of Dilma as a guilty figure that deserves to be punished and removed from office upon popular pressure. This time, memes framed her image in a way that dramatized her defeat as an instrument of validation of the impeachment process itself by showing slightly different perspective from the memes that satirized the voting process and the politicians in the lower house a month before. Similar to the first wave of memes that happened in April, the temporary suspension of Dilma's from office reflected that youth on SNS were able 


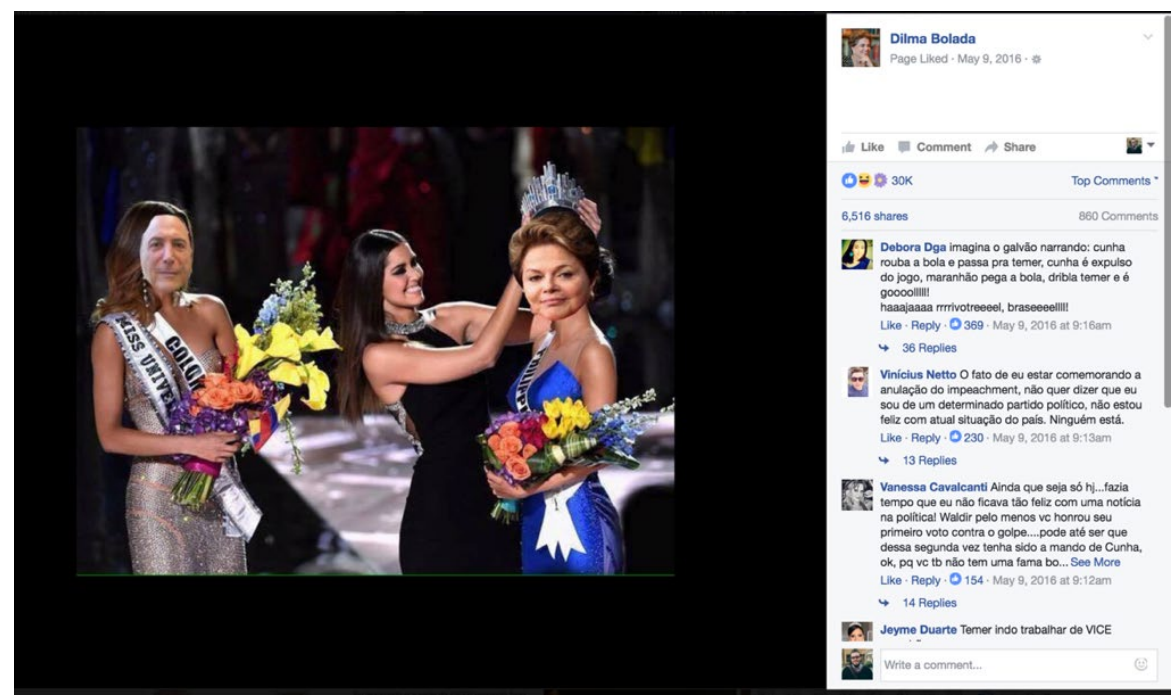

Figure 11: Dilma Rousseff vs. Michel Temer in Miss Universe

The Facebook page Dilma Bolada, a fictional profile about the former president, circulated this meme that refers to the annulment of the voting process. In this case, the meme associates the turning point to the 2015 Miss Universe announcement, when Miss Colombia had to take off her crown and hand it over to Miss Philippines on live television.

to express their political opinion while associating Dilma as the main responsible figure for Brazil's economic recession, high level of unemployment and constant political scandals involving members of the Worker's Party. The hashtag \#TchauQuerida became global trend topic during that day on Twitter and focused on constructing Rousseff's image as a telenovela villain, one who is responsible for slowing down the narrative plot and the final resolution. 


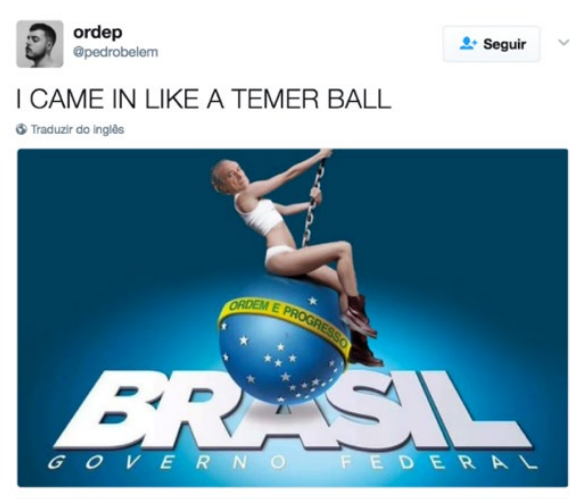

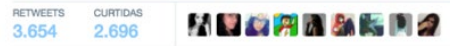

$10: 29$ - 12 de mai de 2016

\& $28 \quad 273,7 \mathrm{mill} \cup 2,7 \mathrm{mil}$

Figure 12: "I came like a Temer Ball"

This memes has three main elements: the photoshopped image of the new President

Michel Temer; the new sign for his political campaign, and the association of these two with the song "I Came Like a Wrecking Ball” by Miley Cyrus (2013).

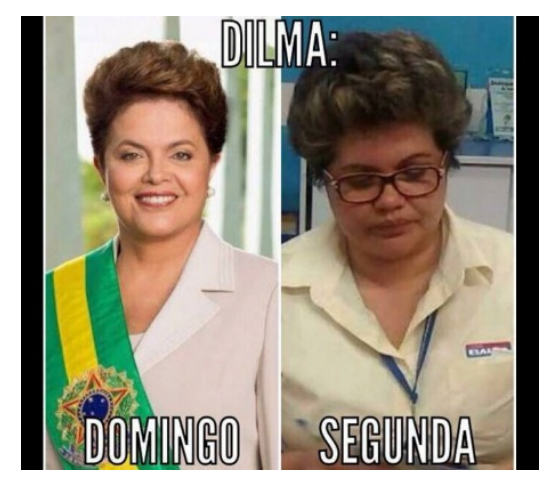

Figure 13: Dilma as President vs. Dilma as part of the working class

The meme refers to Dilma before and after the presidency. The meme suggests that after the impeachment Dilma would have to work at "Casas Bahia," which is a popular retail store network in Brazil.

\section{$3^{\text {rd }}$ Memetic Wave: August 31 ${ }^{\text {st }}$}

The final stages of the confusing impeachment process culminated with Dilma Rousseff being impeached on August $31^{\text {st }}$. Many Brazilians celebrated the results of impeachment on the streets. Additionally, it was possible to observe celebrations across virtual communities as well using Twitter hashtags and Facebook pages. Upon the end of the 13 years of governing by the Worker's Party, youth massively reacted using Internet memes. Once again, blogs and newspapers vigorously published stories about the meme usage in referring to the impeachment scenario. The memes this time once 
again incorporated new behaviors that both celebrated and criticized the decision, reflecting the country's division.

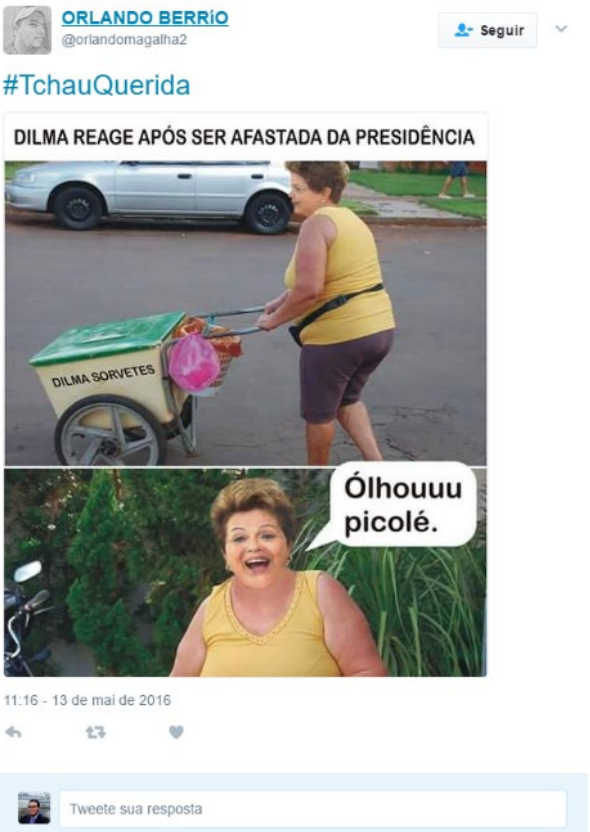

Figure 14: Dilma as an Ice Cream

Seller \#TchauQuerida

This meme speculates what would

happen to Dilma upon the impeachment process. The image suggests that Dilma would end up selling ice cream, satirizing her condition as a politician.

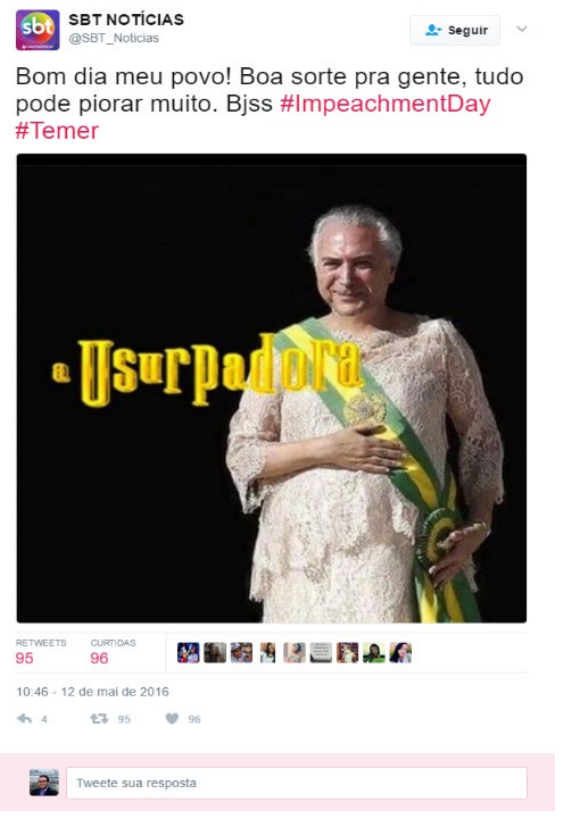

Figure 15: Michel Temer as

Usurpadora \#ImpeachmentDay

The photoshopped meme includes elements both from Dilma Rousseff and the popular Mexican telenovela

Usurpadora, which was widely consumed in Brazil in late 1990s. By placing Michel Temer's face in Dilma's body, the producer placed Temer's

womanized image within the melodramatic context of Usurpadorathat included narrative elements of revenge, power, betrayal, among others. 
However, unlike the previous two waves of memes, the memes upon the impeachment decision incorporated several elements that personified the figure of Michel Temer, the new president who served as Brazil's vice president under Rousseff's administration. In order to do that, memes associated Temer with the fictional character Lord Voldemort. The relationship between the impeachment process
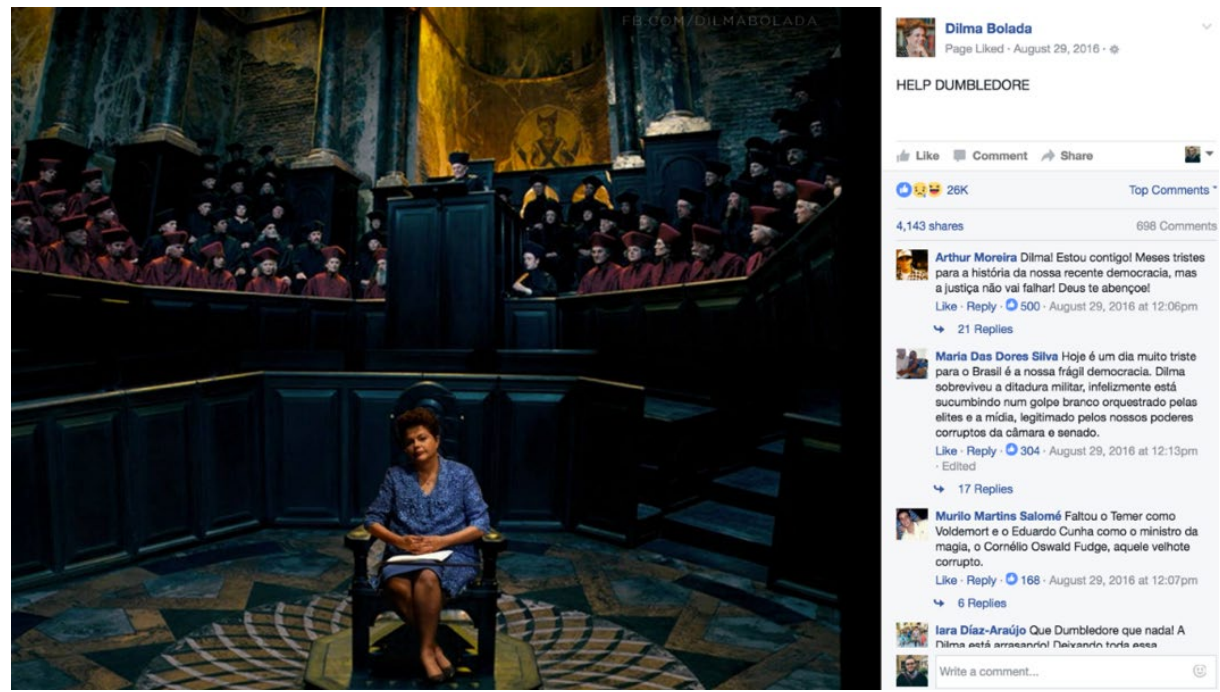

Figure 16: Portrayal of Dilma in the Harry Potter Universe

The Facebook page Dilma Bolada uses this meme to place Dilma Rousseff within the universe of Harry Potter. In this case, Dilma's image is portrayed as if she Dumbledore during the trial by the Minister of Magic in which the character underwent in one of the movies.

and Harry Potter's universe also often was forged at previous situations throughout the political turmoil in Brazil, but it seems that that this sub-genre of memes became much more popular upon Rousseff's defeat. Considering Voldemort as the central main antagonist in the Harry Potter franchise, the memes of the third wave mocked Michel Temer's physical appearance, strategic political mindset, and his choices for the ministries. Similar to the battle of memes that illustrated youth's diverging opinions 
about Rousseff, both as a villain or as a national mother or hero, previously, the memes mocking Temer also illuminated the motivation to render the political crisis in a dramatic way as they incorporate diverse conventions of telenovela. These conventions include fragmented narrative, open plot, interpersonal conflicts, intertextuality, and ambiguity and uncertainty of main characters. Overall, the combination of these narrative conventions - often ingrained in the public imagination-offers the audience the ability to humanize villains and weaken heroes, and vice versa, at any given moment throughout the political turmoil.
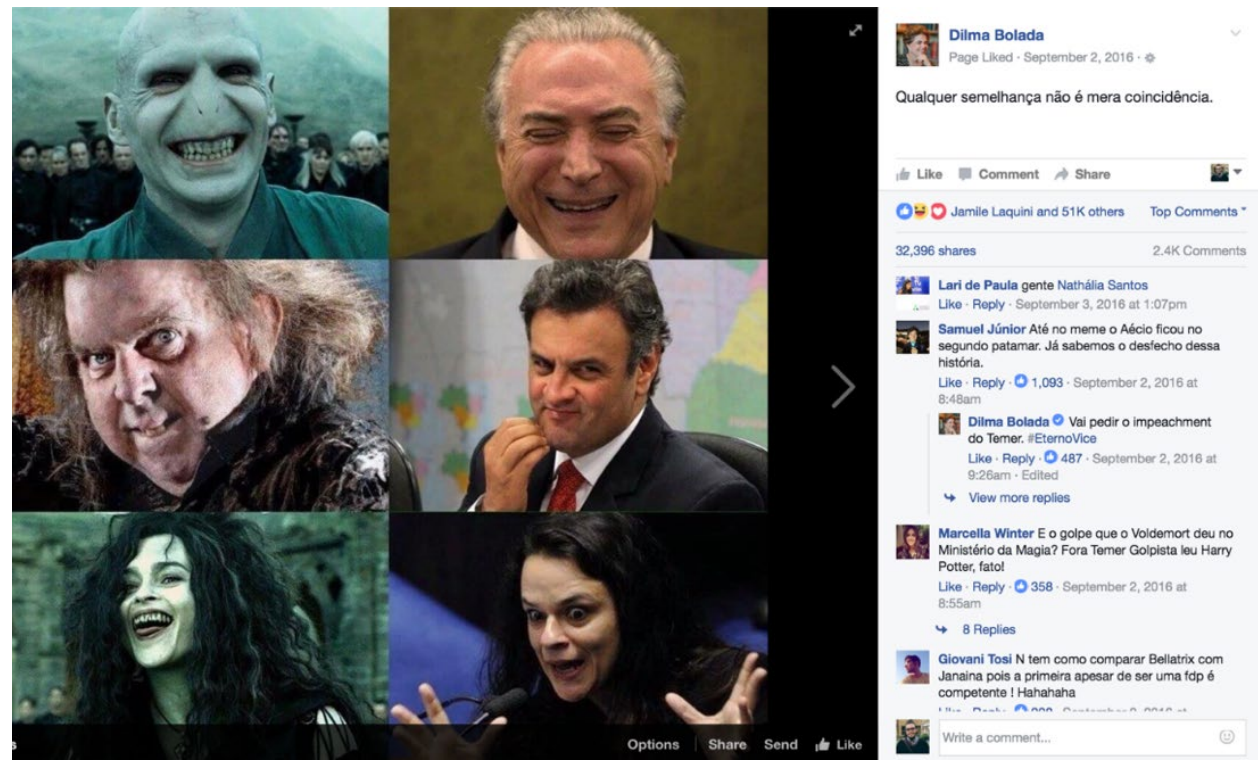

Figure 17: Depiction of right-wing politicians as Harry Potter's enemies The caption for the meme reads: "Any resemblance to reality is pure coincidence." This meme associates the images of right-wing politicians with villains in the Harry Potter franchise, such as Lord Voldemort, Peter Pettigrew, and Bellatrix Lestrange.

Furthermore, memes during the third wave also demonstrated another interesting finding on how Brazilian youth quickly adapt and invent within their own realities and universe of symbolisms. For example, some memes from the third wave incorporated elements of Pokémon Go, the location-based augmented reality game 
developed by Niantic, which was launched in Brazil early August 2016. Such demonstrations of participatory culture among Brazilian youth on SNS enabled to incorporate Pokémon Go in the political discussion around the impeachment process, as well as in other events such as the Olympic Games in Rio de Janeiro.

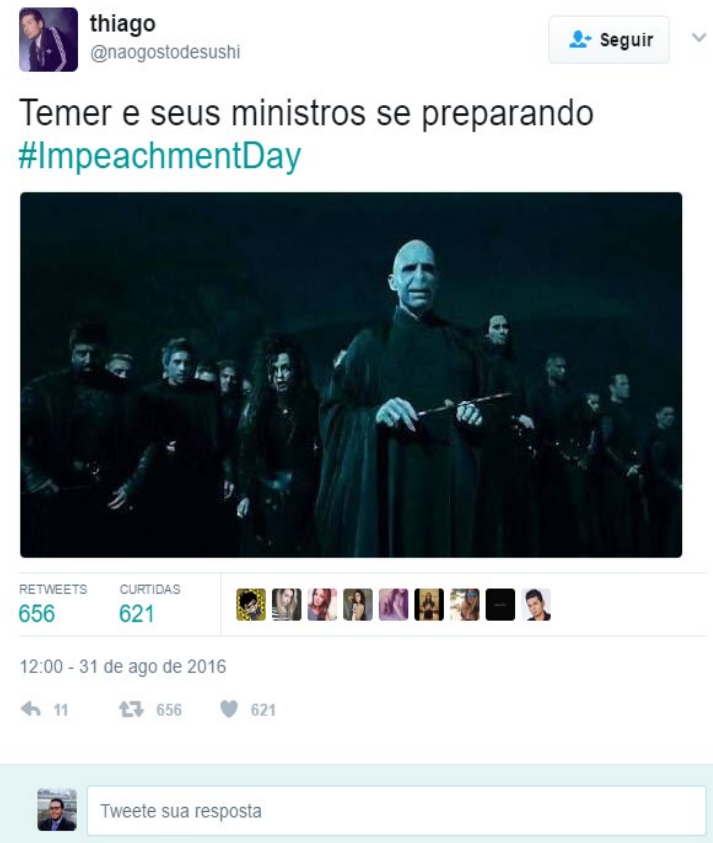

Figure 18: Depiction of Voldemort and his allies as Dilma's enemies The caption for the meme reads: "Temer and his Ministers getting ready." In this case, the meme continues to fuel the relationship between the plot elements in Harry Potter.

On the one hand, youth managed to talk about the impeachment in a way that is funny and provocative, causing humor and likely inciting in-person conversations rather than protesting in physical spaces. On the other hand, memes from each of the identified wave demonstrated to be superficial, ahistorical, tautological, and reactionary. Similar to visual satires from previous centuries, the use of visual humor incites different ways 
to look not only at the political crisis in itself, but also in the way that young Brazilians create meaning around media. Although memes will most likely not be the central driving force behind a political transformation, their use reflects Brazilian youth's creativity and ability to discuss social political events that impact their everyday lives, which are frequently overlooked in dominant media practices. 


\section{Chapter 5: Popular Culture and Intervisuality: The Making of Symbolic Meaning}

Up until this point, my analyses focused mainly on unravelling the current configuration of Brazil's new media landscape and how these shifts enabled the burgeoning of Internet memes as artifacts of participatory culture. In that process, I underscored the notion of Orkut Rule as it provides the specifics of the relationship between Brazilian youth and different aspects of the public sphere. By locating main trends observed in each of the identified waves as they responded to abrupt changes in the impeachment process, I hope to have demonstrated the key sociocultural elements that were juxtaposed in these texts. Another point of concern of this thesis is to understand how the memetic discourse in online spaces evolved and reflected symbolic meaning in the context of the impeachment. As an attempt to answer these second research question, I rely on a critical analysis that aims to connect memes as paratexts that are formed through cultural cannibalism and telenovela conventions.

\section{Memes as Paratexts}

In covering popular memes circulated in the five-month period (from April through September 2016), the previous chapter showed that the most common genre of meme was 'reaction photoshops', which is basically created in response to memetic photos. These memes extensively appropriated Dilma Rousseff's images, highly diverse in social and political contexts, including her iconic — and often controversialinteractions with other leaders from numerous political parties. However, these reaction 
photosphops not only appropriated Dilma's images but also included hybrid texts that were constructed and reconstructed in response to each other as the public discourse branched out.

Internet memes around the impeachment trial in Brazil, often drawn from unrelated contexts, differed from viral media because these texts required a high level of remakes, parodies, and imitations facilitated by active participatory meaning creation by the youth. Henry Jenkins first wrote about participatory culture in 1992, about twenty years before social media became present in everyday life in Brazil. Its broad definition embraces the values of diversity and democracy, considering that individuals can make decisions both individually and collectively.

A participatory culture is a culture with relatively low barriers to artistic expression and civic engagement, strong support for creating and sharing one's creations, and some type of informal mentorship whereby what is known by the most experienced is passed along to novices. A participatory culture is also one which members believe their contributions matter, and feel some degree of social connection with one another (at the least they care what other people think about what they have created). ${ }^{51}$

Participatory culture, in this case, grant youth the power for artistic or creative expressions, although it is difficult to measure the level of civic engagement. When talking about new media, participatory culture also implies that individuals - mostly youth - have the capacity to use a broad range of technologies (both offline and online) to express themselves and their opinions in a way that has a real impact on one another.

In Shifman's model of interpretation of memes and virals, she identifies simplicity, humor, and the participation tools as key aspects of viral and memetic

\footnotetext{
${ }^{51}$ Jenkins, Henry. Confronting the Challenges of Participatory Culture: Media Education for the 21st Century. John D. and Catherine T. MacArthur Foundation Reports on Digital Media and Learning. Cambridge, MA: MIT Press, 2009.
} 
success in digital culture. ${ }^{52}$ Despite the differentiation between the terms, both viral and meme are related to spreadable media in their own unique ways. Jenkins defines spreadable media as "the media which travels across media platforms at least in part because the people take it in their own hands and share it with their social networks." 53 Given the hyper-social culture frequently associated with Brazilians, SNS offered a popular space for participation, turning Brazil's new media landscape into a vast universe of possibilities for spreadable media.

In association with the general Dawkins' ideas on memetics, both viral and memes are correlated to the notion that cultural information is passed from one person to another. However, as pointed out by Shifman, "memetic content is closer to the original idea of the meme as a living and changing identity that is incorporated in the body and mind of its hosts." ${ }^{54}$ Within the context of Brazilian culture, the humor factor in a specific meme seemingly plays one of the most significant role in motivating Brazilian youth to appropriate new media to make political statements, following the Orkut legacy and the well-known Brazilian idiom "a gente ri para não chorar" ("we laugh so we don't cry").

When people understand something quickly and intuitively they are happy to forward it to others. It also encourages memetic responses, since simple content is easy to imitate. Humor augments sharing, as people wish to amuse their friends and to be associated with wittiness, but it also augments the tendency to imitate and remake content, given

52 Shifman, Limor. Memes in Digital Culture. MIT Press Essential Knowledge Series. Cambridge, Massachusetts: MIT Press, 2014, 95.

53 “Why spreadable doesn’t equal viral: A conversation with Henry Jenkins.” Nieman Lab. Accessed April 07, 2017. http://www.niemanlab.org/2010/11/why-spreadable-doesnt-equal-viral-a-conversationwith-henry-jenkins/.

54 Shifman, Limor. Memes in Digital Culture. MIT Press Essential Knowledge Series. Cambridge, Massachusetts: MIT Press, 2014, 56. 
its association with playfulness, incongruity, and feelings of superiority. ${ }^{55}$

Hence, as demonstrated by the memes from the three identified waves in Chapter 5,

Internet memes in Brazil do not function only because of humor or superficial elements.

Instead, they also function as gateway for expression to discuss the country's most controversial and difficult issues, becoming a paratext for engagement for those who for

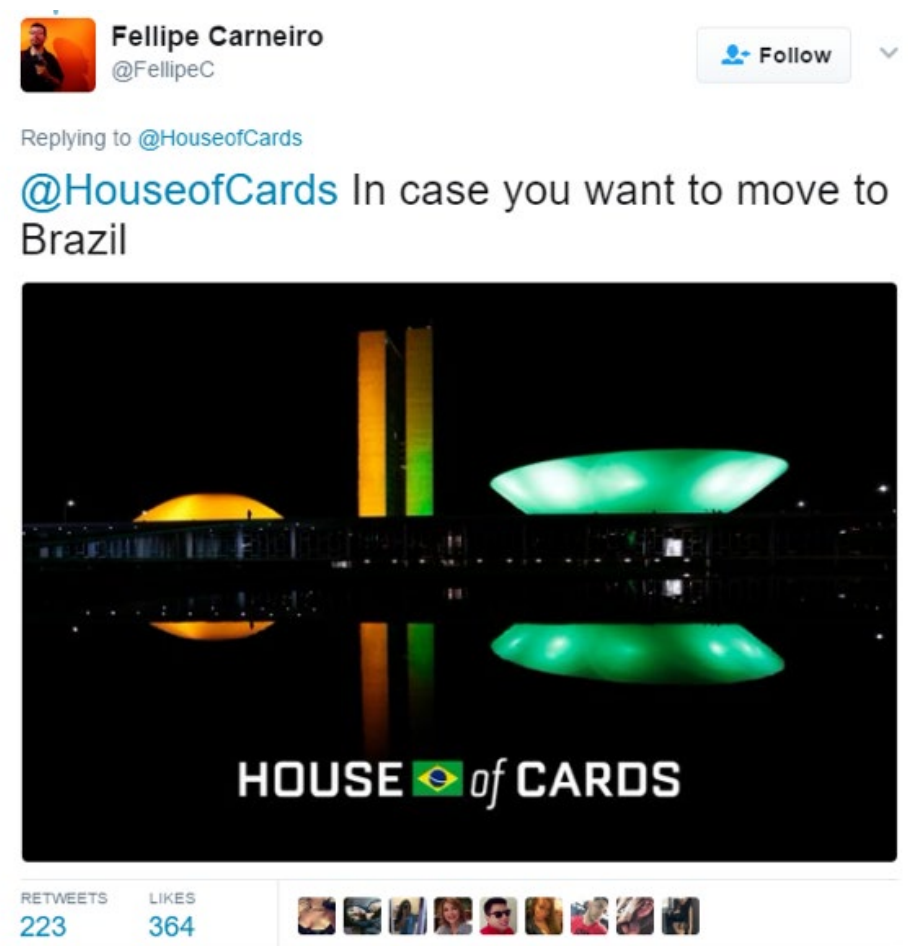

Figure 19: Brazilian Congress and House of Cards

House of Cards is an American political drama originally released in 2013. During the impeachment in Brazil, users referred to the political scenario as it was a plot from the show. Even the official House of Cards' social media channels mocked the turning points throughout the impeachment.

long have been unable to engage with the public sphere. Moreover, Shifman's focus on simplicity, humor, and participation as tools in the relationship between memetic and viral success elucidates that Internet virals and memes represent different modes of

${ }^{55}$ Ibid., 96. 
engagement online rather than passive versus active formulations - after all, viral can be turned into a meme with many derivatives.

Regardless of the type of media produced, youth are the central figure for such practice. In fact, as demonstrated in past remarkable social movements, youth have proved to be the foremost group capable of carrying out social changes; therefore, they are the ones capable of breaking geographic and socioeconomic barriers to engage in discussions about societal issues. This could not be more evident in today's world with increased access to the Internet. In 2017, for example, the Oxford Dictionaries Word of the Year 2017 was 'youthquake', which is defined as "a significant cultural, political, or

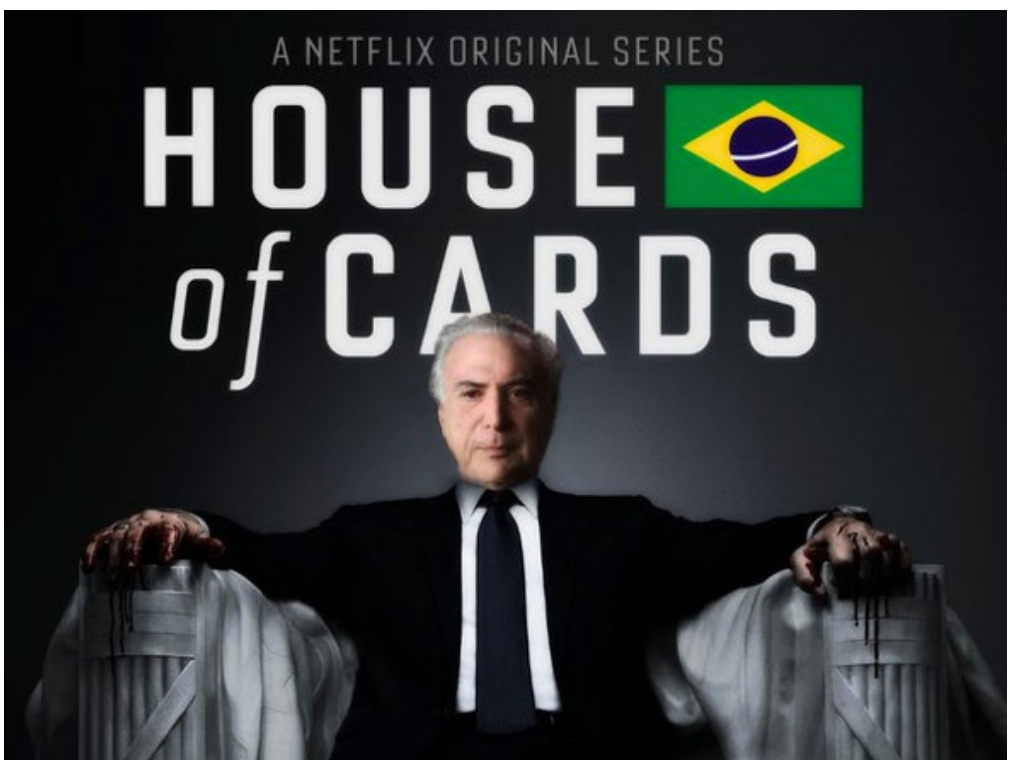

Figure 20: Depiction of Michel Temer as Frank Underwood

The meme places Michel Temer's face in the main character of House of Cards, Frank Underwood. There were other versions of the meme using the face of other politicians.

social change arising from the actions or influence of young people." 56

\footnotetext{
56 "Word of the Year 2017 Is..." Oxford Dictionaries | English. Accessed May 01, 2018. https://en.oxforddictionaries.com/word-of-the-year/word-of-the-year-2017.
} 
When in relation to new media, youthquake will continue to challenge dominant media practices because for the first time it is allowing more inclusive civic participation due to the democratization of new media technologies. The ways in which these challenges occur, however, are dependent on the agency of young people, which, as I argue, is deeply related to the country's culture. Having said that, the concept of the Orkut rule apparently holds importance when discussing the use of memes during the impeachment process because it demonstrates how youth deploy digital technology and social media to question class inequality, corruption, issues of representation, democracy, race, gender, and so on.

In creating content worlds, Brazilian youth appropriate inventive ways to represent, critique, or recreate the public sphere during the impeachment trial (fig. 19 and fig. 20). Participatory politics, as an expansion of the concept of participatory culture, allows for a more coherent contextualization of the interplay between memes and the political context. Although optimistic, it is rather challenging to create content worlds that foster civic participation in the real world at the same time it does in virtual communities. About offline implications of Internet memes, Elizabeth Soep writes that stories can take on lives of their own fueled by social media dissemination. Soep believes that such stories "can traffic in ideologies that run counter to the best interests of the people with the most at stake in what happens next." ${ }^{, 57}$

In sustaining critical messages from online to the public sphere, time is one of the most important challenges in the distractive digital culture. Soep claims that if the

\footnotetext{
${ }^{57}$ Soep, Elisabeth. Participatory Politics: Next-generation Tactics to Remake Public Spheres. John D. and Catherine T. MacArthur Foundation Reports on Digital Media and Learning. Cambridge, Massachusetts; London: MIT Press, 2014, p. 21.
} 
goal is to sustain a critical message "a meme often sets a clock ticking, which before long can turn a clever trope into a tired gimmick, effectively retiring the message whose substance might still deserve serious attention long after the meme has timed out." 58 Nevertheless, I argue that Brazilian youth will continue to use memes to criticize and contrast societal controversies using Brazil's hybrid and open culture; therefore, it is necessary to find a model that better locates Internet memes as a new media expression capable of impacting the public sphere instead of classifying them exclusively as useless user-content based on humor. Given the influence of popular culture in the formation of individual and cultural identities, it is clear that popular culture is the fabric of what makes meme so prominent, relatable, and engaging. This is deeply related to Soep's argument regarding participatory politics when she argues "pop culture thus serves as a platform through which individuals can communicate with each other about politics in a playful and engaging way. ${ }^{59}$

\footnotetext{
${ }^{58}$ Ibid., p. 24.

${ }^{59}$ Shifman, Limor. Memes in Digital Culture. MIT Press Essential Knowledge Series. Cambridge, Massachusetts: MIT Press, 2014, p. 136.
} 


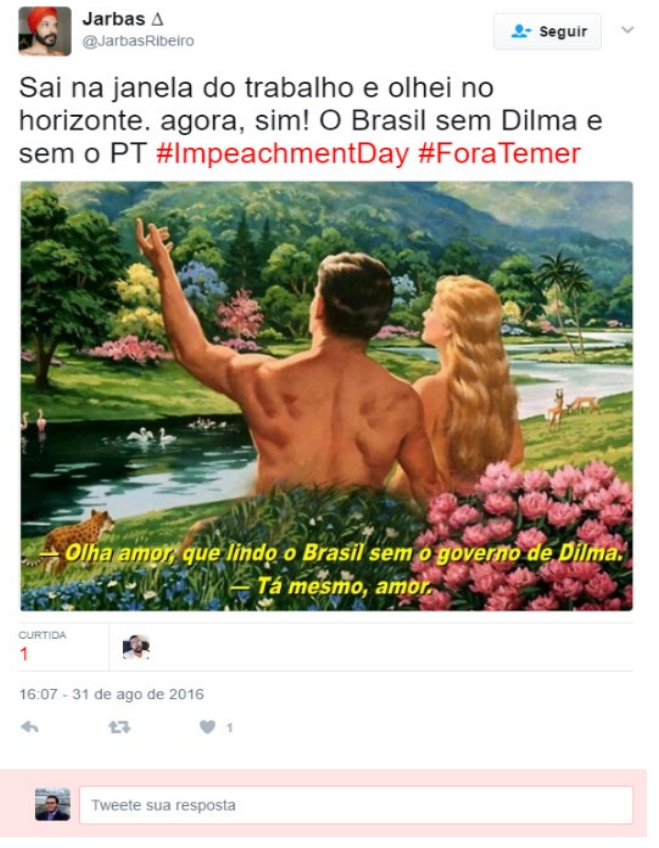

Figure 21: Satirical depiction of Brazil without Dilma Rousseff

This meme ironically uses elements from the books used by followers of Jehovah witness. The text within the image translates: "Look, love, how beautiful Brazil is without Dilma's government." And the female character supposedly answers: "It is true, love." In this case, the meme leads to a discussion regarding the role of democracy and political figures in solving societal issues.

Since popular culture is doomed to continue shaping the relationship between youth and politics, I claim that Internet memes around the impeachment function as a trope of paratext, one that allows Brazilian youth to communicate about the political turmoil of the country using trends from their set of cultures. In doing so, these same memes may have brought the attention to the need of understanding memetic media as an important tool to instigate a discussion that emerges in virtual communities and can trigger other forms of engagement in the public sphere, even if it is via humor.

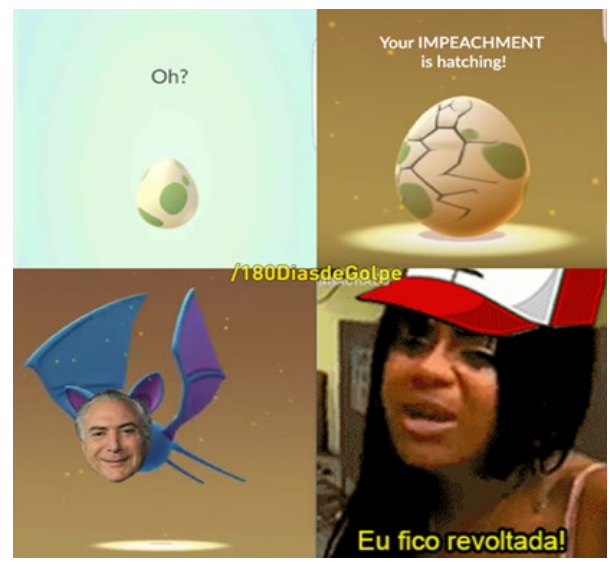

Figure 22: Depiction of the Impeachment via Pokémon Go

In August 2016, the mobile application Pokémon Go was launched in Brazil. Since it was the final month for the impeachment process, youth also managed to associate elements from the game to talk about the impeachment. 
Meninas no vídeo de hoje vou ensinar como reestabelecer a democracia no Brasil \#ImpeachmentDay \#foratemer

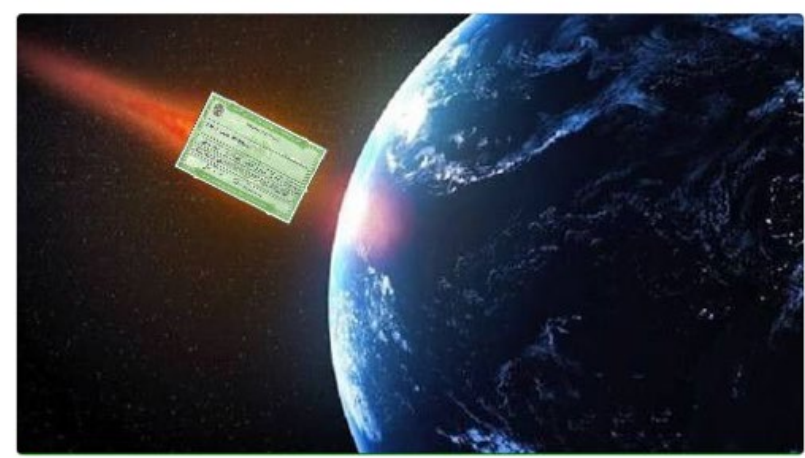

RETWEET

1

17:57 - 31 de ago de 2016

h 271

Tweete sua resposta

Figure 23: Tutorial on How to Reestablish Democracy in Brazil

The meme plays with the role of the national card that allows people to vote. In Brazil, voting is mandatory so every citizen is required to hold Título de Eleitor.

\section{Life is a Drama: Agency, Telenovela, and Cannibalism}

In this section, I suggest the idea that the memetic intervisuality embedded in these memes are closely related to two aspects of Brazil's popular culture: television and the notion of cultural cannibalism. To do so, I use Kenneth Burke's dramatistic pentad. While I do not focus on the audiences' motifs, I hope that Burke's understanding of life as a drama coupled with the pentad as a tool will help contextualize the new media practice that this thesis addresses. 


\section{Dramatism and Burke's Pentad}

In the late 1970s, literary critic Kenneth Burke postulated an interpretive and critical method to help explain the intricacies behind human relations and the motives involved in all spheres of society. Commonly referred as dramatism, Burke claims that life, as any captivating film or theatre, is heavily dependent on dramatization in the process of motivating audiences into actions. Closely linked to one of Shakespeare's acclaimed theatrical texts that reads "all the world is a stage / and all the men and women are merely players, ${ }^{60}$ Burke suggests that the world as we know it functions as a metaphorical stage where humans are actors, writers, directors, and audiences simultaneously. This key argument is rooted in three essential aspects: identification, guilt-redemption, and the dramatistic pentad. ${ }^{61}$

Despite the oftentimes criticized large scope of his claims, Burke offers valuable insights not only about how to effectively communicate a message, but also how to locate the set of motives behind a particular situation. ${ }^{62}$ For the goal of this research, nonetheless, I focus essentially on the dramatistic pentad given its pragmatic utility in helping contextualize the three memetic waves I defined in the previous chapter. To put it another way, the fervent theoretical debates over dramatism are left out since the matter of interest here is the pentad as an instrument of qualitative analysis.

\footnotetext{
${ }^{60}$ Shakespeare, William. “As You Like It, Act II, Scene VII [All the world's a stage].” Poets.org. June 16, 2016. Accessed February 10, 2018. https://www.poets.org/poetsorg/poem/you-it-act-ii-scene-vii-allworlds-stage.

${ }^{61}$ Burke, Kenneth. A Grammar of Motives. Berkeley: University of California Press, 1969, passim.

${ }^{62}$ Glenister Roberts, Kathleen. Communication Theory and Millennial Popular Culture: Essays and Applications. New York: Peter Lang, 2016, 24.
} 
As an analytical method, the dramatistic pentad includes five components: act, scene, agent, agency, and purpose. Similar to the traditional information-gathering principles from journalism tradition (what, where, who, how, and why), the pentad help identifies one's motives in a particular situation. As Burke explains:

In a rounded statement about motives, you must have some word that names the act (names what took place, in thought or deed), and another that names the scene (the background of the act, the situation in which it occurred); also, you must indicate what person or kind of person (agent) performed the act, what means or instruments he used (agency), and the purpose. ${ }^{63}$

In addition to unraveling the creative pursuits behind the changes reflected on the memes in each of the three waves, I will pinpoint specificities that might be useful in comprehending new media practices within the context of Brazilian culture. However, the main goal here is to critically identify trends in the development of the memetic discourse during the impeachment period; thus, the focus is not to provide a unique motif as it would be nearly impossible to accomplish given the political fragmentations around the impeachment. Coupled with the previous discussion on what generally characterized the content on memes that have massively been circulated in relation to the media and the political discourse, the pentad demonstrates to be useful for analyzing several parallel scenes of action in different contexts, which in this case reflected the dramatic turning points during the impeachment process.

\footnotetext{
${ }^{63}$ Burke, Kenneth. A Grammar of Motives. Berkeley: University of California Press, 1969, xv.
} 


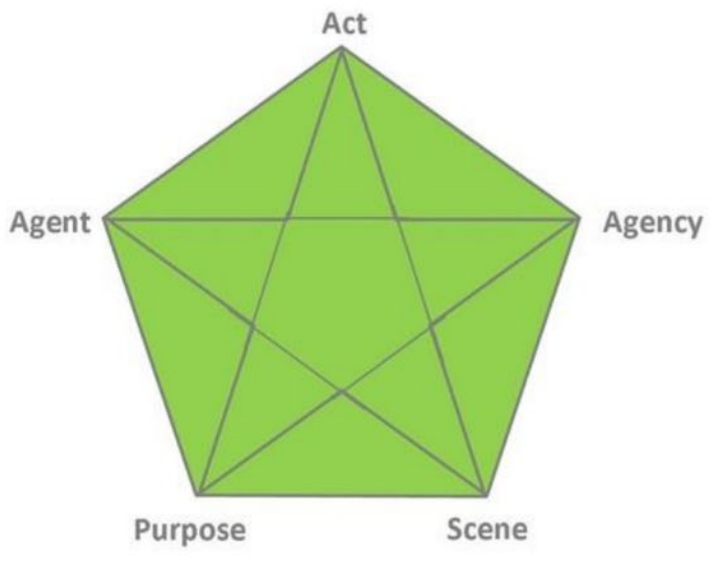

\begin{tabular}{l|l} 
ACT & $\begin{array}{l}\text { What is being } \\
\text { done }\end{array}$ \\
\hline AGENCY & $\begin{array}{l}\text { Mean by which } \\
\text { an action occurs }\end{array}$ \\
\hline AGENT & $\begin{array}{l}\text { Person doing } \\
\text { the act }\end{array}$ \\
\hline SCENE & $\begin{array}{l}\text { Setting background } \\
\text { for action }\end{array}$ \\
\hline PURPOSE & $\begin{array}{l}\text { Reason or rationale } \\
\text { behind action }\end{array}$ \\
\hline
\end{tabular}

Table 1: Kenneth Burke’s Dramatistic Pentad

Before proceeding with the dramatistic pentad, however, it is important to underscore what I wrote in Chapter 3-the fundamental fact that Internet memes need to be understood as artifacts, given their meaningful relationship to cultural, technological, and historical elements. Particularly in relation to politics, artifacts also hold extreme importance as they "reflect communication and society, train us to communicate, and provide tools needed to adapt to different situations." ${ }^{64}$ Memes as artifacts, in this case, also showcase the creative ways in which young Brazilians attempted to persuade others in relation to the public discourse around the impeachment process. Before delving into the details of my critical analysis, I apply Burke's dramatistic pentad for each of the identified waves below, which has already been discussed in details in Chapter 4.

\footnotetext{
${ }^{64}$ Ibid., p. 24.
} 
Table 2: 1st Memetic Wave - Prelude

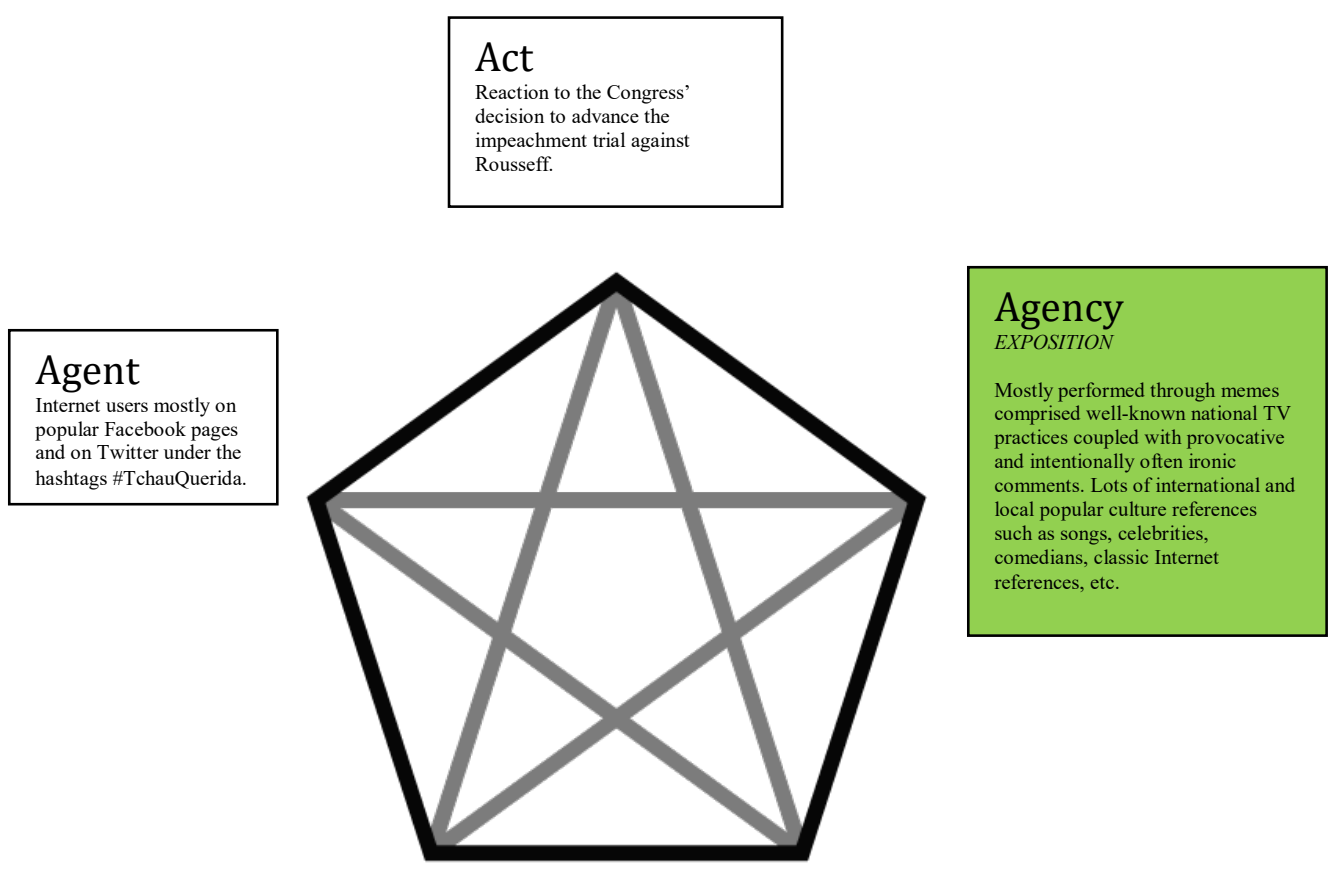

\section{Purpose}

i) To satirize the inconsistencies

epitomized by politicians who

delivered their vote against

Rousseff;

ii) To celebrate the decision of an

official appeal to remove

Rousseff from office.

\section{Scene}

Following uncountable

protests that took place across

Brazil coupled with drastic

changes in the economy, the

Congress conducts a voting

session in favor of the

impeachment against Rousseff

in Brasilia, accusing her of

violating the budget law. This

first important voting was

broadcasted in national TV and

lasted for many hours. 
Table 3: 2nd Memetic Wave - Central phase

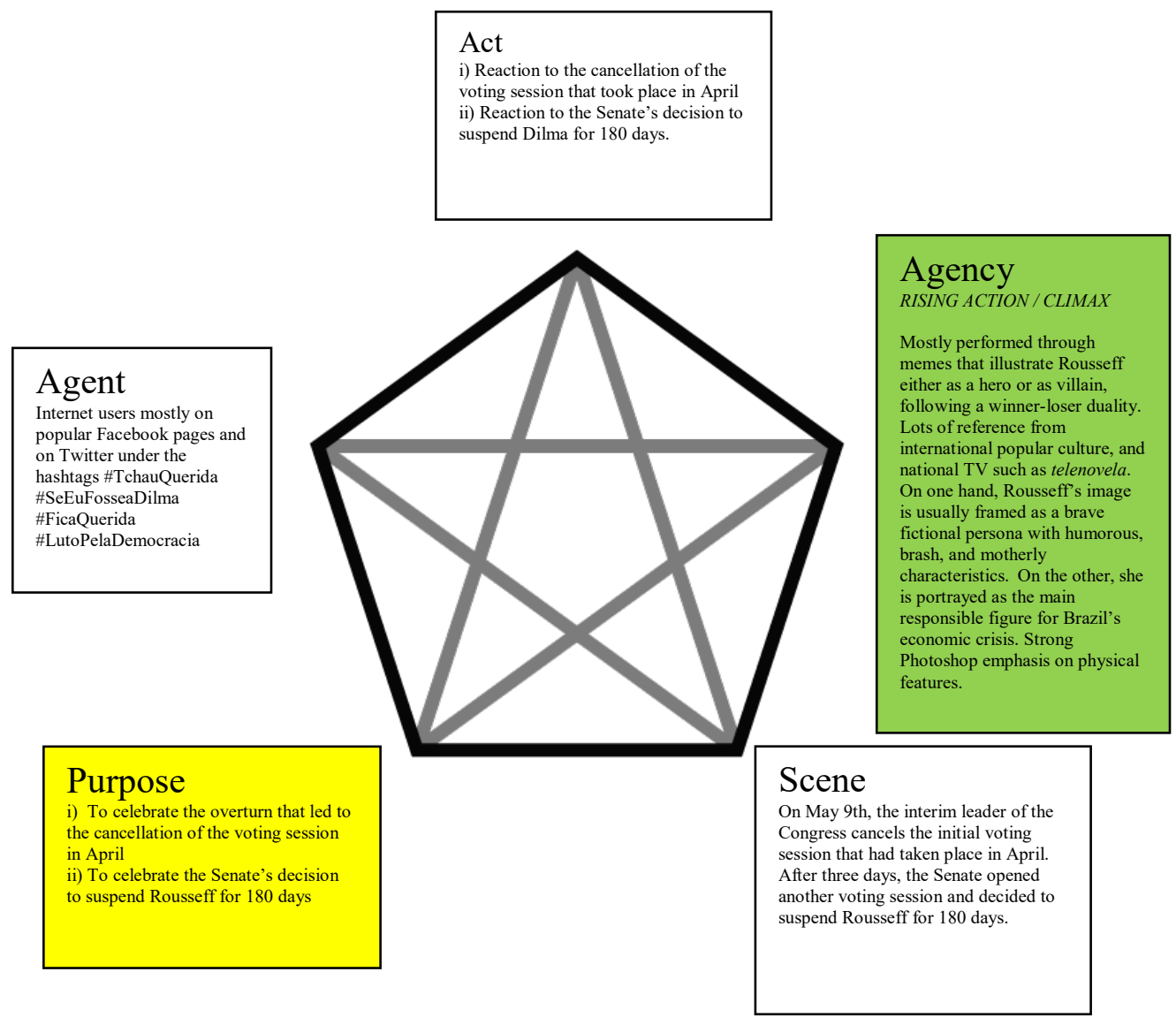

Table 4: 3rd Memetic Wave - Ultimate phase 


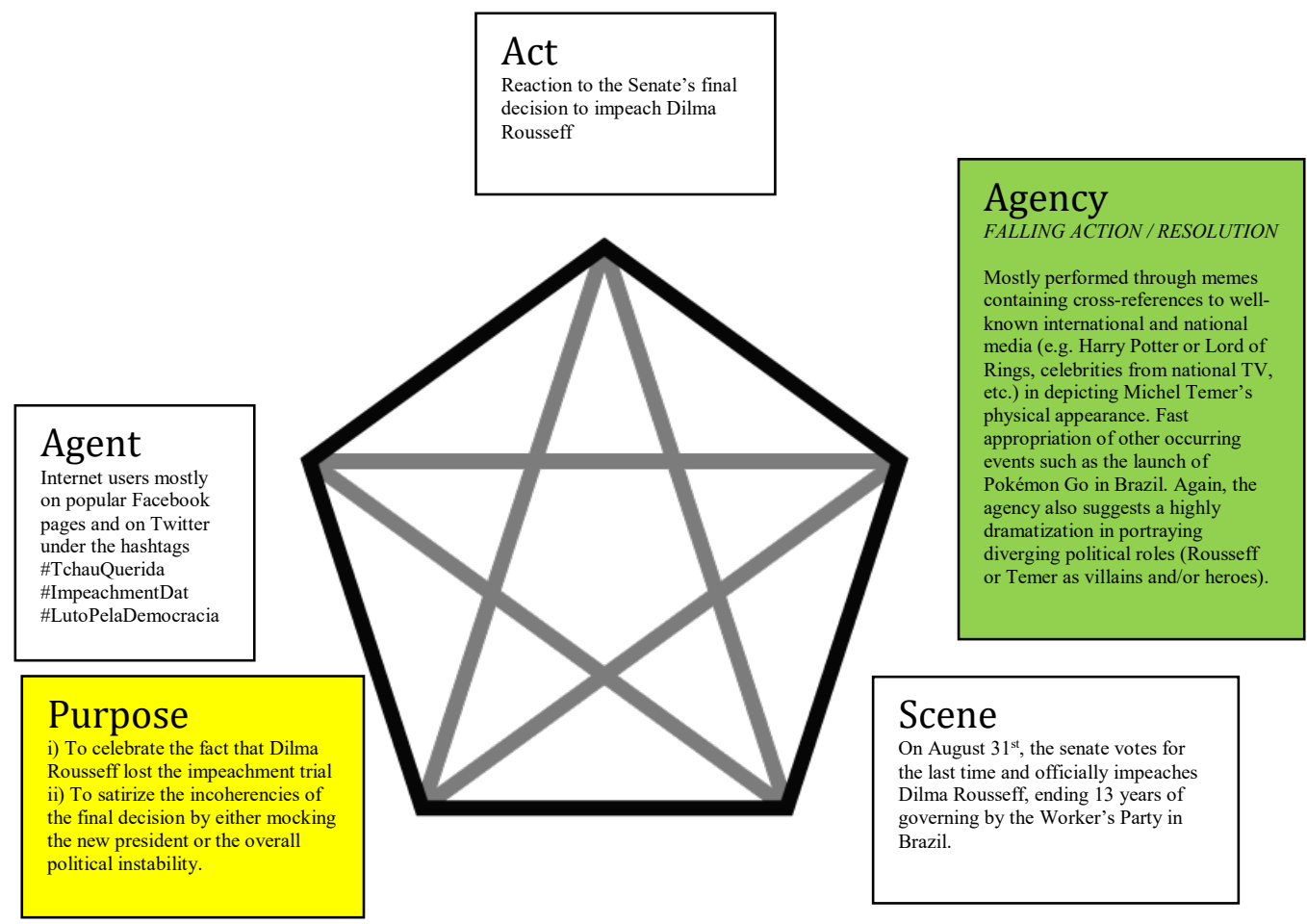

Agency-purpose Ration: The Available Tools Shape a Person's Intentions

By breaking down the complex nuances of the impeachment via the Burke's pentad, it is possible to note that each one of three waves appears to show an interesting pattern. While I tried to be as neutral as possible, I also acknowledge that there may be shortcomings or simplifications in the breakdown. In general, however, the act seemingly reflected a reactionary behavior in response to rapid and often unexpected changes in the scene; that is, the political escalations that became present in everyday discussions across all media systems, from TV channels to newspapers. The scene is, accordingly, crucial for contextualizing the ways in which memes 'talked' not only with each other, but also with the 'public discourse itself' of a given moment. As discussed in Chapter 2, the action is conducted by the active and savvy SNS users of Facebook 
and Twitter, which in the pentad is represented under the dimension of the agent. While it is a difficult task to track individual groups or specific online communities that created certain memes, considering that they are easily circulated and appropriated in new cultural meanings, both aesthetically and politically, hashtags offered some guidance in regards to the agent behind these texts.

Nevertheless, more pervasive for this research is the agency-purpose ratio that is evident throughout the memetic waves. In this case, the agency-purpose ratio is fundamental in comprehending the ways in which memes shaped the public discourse around impeachment, as the rhetorical strength of the agency, as commonly agreed upon, resides in its ability to dominate other terms. After all, as structured by Ragan Fox in his interpretive framework of Burke's ratios breakdown, the agency-purpose ration drives the notion that "the available tools shape a person's intentions." 65 Observed in all pentads above, the computer-mediated agency used remains the same even when the purpose is polarized. Having said that, I argue that such reoccurring agency throughout in the creation of Internet memes reflect the popular culture references epitomized essentially by telenovela and cultural cannibalism. As highlighted in each individual pentad, unrelated to the purpose or intention, the agency remained the same: one that powerfully draws storytelling elements from popular culture and gains sociological meaning with the juxtaposition of seemingly unrelated texts, which is, as I will argue, explained by cultural cannibalism.

\footnotetext{
${ }^{65}$ Raganfox. "Ragan Fox Breaks Down Kenneth Burke's Pentadic Ratios." Dr. Ragan Fox. October 21, 2013. Accessed April 24, 2018. https://raganfox.wordpress.com/2013/10/21/ragan-fox-breaks-downkenneth-burkes-pentadic-ratios/.
} 
On the one hand, Internet names, as demonstrated via the dramatistic pentad represented by the agency, function as a mirror that reflects cultural and media practices. On the other hand, the polarized purposes identified in each wave reflect the unstable politics, and the fragmentations in the public discourse about the impeachment. Regardless of the agent's purpose, agency will likely continue to shape cultural practices among youth, which justifies the importance for more studies on the topic considering Brazil's fast-evolving new media landscape. Therefore, this follows Shifman's argument that "human agency is an integral part of our conceptualization of memes and because they represent dynamic entities that spread in response to technological, cultural, and social choices made by people." ${ }^{66}$ While it is difficult to locate a model that explains all memes created around the impeachment, I offer a new way of looking at these texts in the next section. As an introductory argument, I recognize that more research needs to be done, but I offer this idea as a new way to consider memes as artifacts that reflect the specifics of the place it emerges and how they gain symbolic meaning when created collectively via participatory culture.

\section{Memetic Discourse via Telenovela Plotlines and Cannibalism}

Whereas the agency remained essentially the same, the plotline of the memetic discourse clearly resonates with common telenovela conventions. Telenovela ${ }^{67}$ is a

\footnotetext{
${ }^{66}$ Shifman, Limor. Memes in Digital Culture. MIT Press Essential Knowledge Series. Cambridge, Massachusetts: MIT Press, 2014, p. 189.

${ }^{67}$ Maria Immacolata Vassallo De Lopes, professor at the School of Communication and Arts (ECA) of University of São Paulo, defines telenovela as television fiction's format. According to her, telenovela emerged in 1963, and can be defined as a fictional narrative of long serialization; it is shown daily with a duration of about 200 chapters. That is, it is aired six days per week and has an average length of eight months.
} 
television melodrama genre inspired by American TV soap opera, and it is often permeated by western capitalist values such as consumerism, and the embellishment of class conflicts, where the American lifestyle reappears with a 'Brazilian face.' In this sense, telenovela exemplifies the process through which the external cultural imperialism has been replaced by Brazilian characters, usually led by politicaleconomic elites. Despite the unreal portrayal of the country's realities, the underlying reason for telenovela being considered as a 'national obsession' amongst most Brazilians is closely related to the country's complex colonial history, inequality level, functional illiteracy, and many others. As one writer of telenovelas elaborated:

The artistic roots of us Brazilians don't come from the Greek theater, they come from the circus. We are a people of the Third World, a poor and ignorant people. I want to talk to my people in language they understand. Thus neither humor nor imagery could be overly subtle. ${ }^{68}$

Therefore, telenovela can be understood as a creative version of a possible Brazilian national story, ${ }^{69}$ which contributed to turning television into the most popular and influential media technology in Brazil, as I elaborated in Chapter 2. Currently, the telenovela genre is also expanding its contemporaneous relevance by representing the voice of the youth who are increasingly more connected to the Internet and who tend to create new media. In an effort to attract young audiences, telenovela increasingly incorporates more progressive topics such as same-sex marriage, immigration, adoption, human trafficking, social justice and other taboos or societal issues in their narratives.

\footnotetext{
${ }^{68}$ Page, Joseph A. The Brazilians. Reading, Massachusetts: Addison-Wesley Publishing Company, 1995, p. 453.

${ }^{69}$ Oliveira, Omar S. Brazilian soaps outshine Hollywood: is cultural imperialism fading out? In: Nordenstreng K, Schiller HI (eds) Beyond National Sovereignty: International Communication in the 1990s. Norwood, NJ: Ablex, 116-131.
} 
As a televisual practice with magnificent cultural power, telenovelas are easily recognizable because "they grew out of the history of popular culture, having historical matrices in ancient oral and literary storytelling as well as in more recent narrative mass communication."70 Considering the relevance of TV practices in Brazil, most Brazilians are raised having daily access to telenovelas as part of their family culture-regardless of their socioeconomic class, gender, or even geographic location. In his discussion of the historical matrices of Brazilian telenovela, Thomas Tufte identifies sociability, collective activity, and entertainment as "the common denominators in the role that oral cultures have played in Brazilian history and in the role that telenovelas play in contemporary Brazil society." ${ }^{, 71}$ Aside from the different styles and conventions deployed by different TV channels, the essence to captivate the audience's remains the same to the present day. But what are the connections between telenovela practices and the dramatistic pentad of memes about the impeachment?

Similar to the agency-purpose ration highlighted in the dramatistic pentad, Brazilian telenovela is often produced under a highly complex dramaturgy, linking stories contained in a single episode to others spanning the series. According to Decio Pignatari, the plot of Brazilian telenovela can be broken down into (a) first phase, (b) central phase, and (c) ultimate phase as illustrated in the chart below. ${ }^{72}$

\footnotetext{
${ }^{70}$ Tufte, Thomas. Living with the Rubbish Queen: Telenovelas, Culture and Modernity in Brazil. Luton, Bedfordshire, UK: University of Luton Press, 2000, p. 87.

${ }^{71}$ Ibid., p. 94.

72 Pignatari, Décio. Signagem da televisão. Sao Paulo: Brasiliense, 1984, pp. 60-85.
} 


\begin{tabular}{|c|c|c|}
\hline Phases & Episodes & Plot characteristics \\
\hline First phase & $\begin{array}{l}\text { Prelude of } \\
30-40 \\
\text { episodes }\end{array}$ & $\begin{array}{l}\text { All possibilities are laid open; } \\
\text { two or three themes are emphasized; and } \\
\text { The characters are rather vague. }\end{array}$ \\
\hline Central phase & $\begin{array}{c}\text { Contains at } \\
\text { least } 100 \\
\text { episodes }\end{array}$ & $\begin{array}{c}\text { The plot starts to develop; } \\
\text { Characters get clearer profiles; } \\
\text { Primary and secondary plots are hierarchized and } \\
\text { made plain; and } \\
\text { The narrative proceeds slowly and undergoes } \\
\text { turning points. }\end{array}$ \\
\hline Ultimate phase & $\begin{array}{l}\text { Contain at } \\
\text { least } 30 \\
\text { episodes }\end{array}$ & $\begin{array}{l}\text { Closure of the narrative is carried out; } \\
\text { Some characters are suddenly changed; and } \\
\text { Some characters disappear and new ones turn } \\
\text { up in order to resolve the puzzle that has been } \\
\text { set up by the profusion of plotlines. }\end{array}$ \\
\hline
\end{tabular}

Table 5: Telenovela plotline conventions breakdown by Brazilian essayist Decio Pignatari (1984)

Based on the chart above, there seems to be a strong correlation between plot characteristics observed in Brazilian telenovelas with the creation and circulation of political memes in the period analyzed. In each wave described earlier in the chapter, it is possible to locate evidence that supports this interpretation. For instance, the sceneact ratio, that is, the dimension which assumes that setting determines action, reveals the openness that is frequently found in Brazilian telenovelas. Silvio de Abreu, one of Brazil's most acclaimed telenovela directors, observes: 
Everything can be incorporated into the narrative: an accident seen in the street, a fight, a piece of gossip you just heard, a protest against the situation in the country, a reflection on society. Everything is of interest. The dramatic structure of telenovela is so ample it allows you to go in any direction at all. ${ }^{73}$

Mostly during the central phase, the openness of the narrative - or of the public discourse via memes - gives ample opportunity to incorporate the audience's response, which in the case of the impeachment is related to the many turning points throughout the escalating political turmoil.

If the plot breakdown helps contextualize the symbolic meaning concerning the consistency of the agency-purpose ratio throughout the period analyzed in reaction to different 'scenes', the heroes and anti-heroes characteristic of telenovelas is the centerpiece behind the portrayal of Dilma Rousseff and Michel Temer. As it is expected for the ultimate phase, the dichotomy between good and evil (or left- or right-wing) gains stronger relevance for the public discourse as the impeachment came to an end. When associated with the openness and uncertainty of the plot, such dichotomy also helps guide the plot or public discourse into a positive or happy resolution, as it was observed in the third wave. In addition to the telenovela conventions observed throughout the identified waves, the visual juxtaposition of unrelated elements as part of hero and anti-hero dichotomies can be largely clarified via the notion of cultural cannibalism, which gained strength at the end of the 1920s.

Emerging as part of the Brazilian modernism, the idea of cultural cannibalism was presented in the Manifesto Antropofagico (Cannibalist Manifesto) by the artist Oswald de Andrade in 1928. As an attempt to deviate from artistic European

\footnotetext{
73 Tufte, Thomas. Living with the Rubbish Queen: Telenovelas, Culture and Modernity in Brazil. Luton, Bedfordshire, UK: University of Luton Press, 2000, p. 114.
} 
conventions, the Manifesto proposed the incentive to forge and validate a unique postcolonial Brazilian identity. Highly polemical even for the intellectual community of the time it was created, the Manifesto starts as the following:

"Only Cannibalism unites us. Socially. Economically. Philosophically. The unique law of the world. The disguised expression of all individualisms, all collectivisms. Of all religions. Of all peace treaties. Tupi or not Tupi that is the question." 74

Given the poetic nature of the manifesto, it is highly difficult to translate it to an English-speaking audience. Regardless, as argued by Leslie Bary, the Manifesto challenges "the dualities civilization/barbarism, modern/primitive, and original/derivative, which had informed the construction of Brazilian culture since the days of the colony." ${ }^{75}$ Working as a powerful a metaphor, in this case, the idea of cannibalism does not refer to the denial of European culture; rather, it refers to the need of 'devouring' European culture and 'vomiting' something that is uniquely Brazilianwhich is, according to De Andrade, Brazil's greatest strength. ${ }^{76}$

\footnotetext{
${ }^{74}$ De Andrade, Oswald. “Manifesto antropófago.” Nuevo Texto Crítico 12, no. 1 (1999): 25-31.

${ }^{75}$ Bary, Leslie. “Oswald De Andrade's 'Cannibalist Manifesto'.” Latin American Literary Review 19, no. 38 (1991): 35-47.

${ }^{76}$ Avramidis, Konstantinos, and Tsilimpounidi, Myrto. Graffiti and Street Art : Reading, Writing and Representing the City. New York: Routledge, 2017.
} 


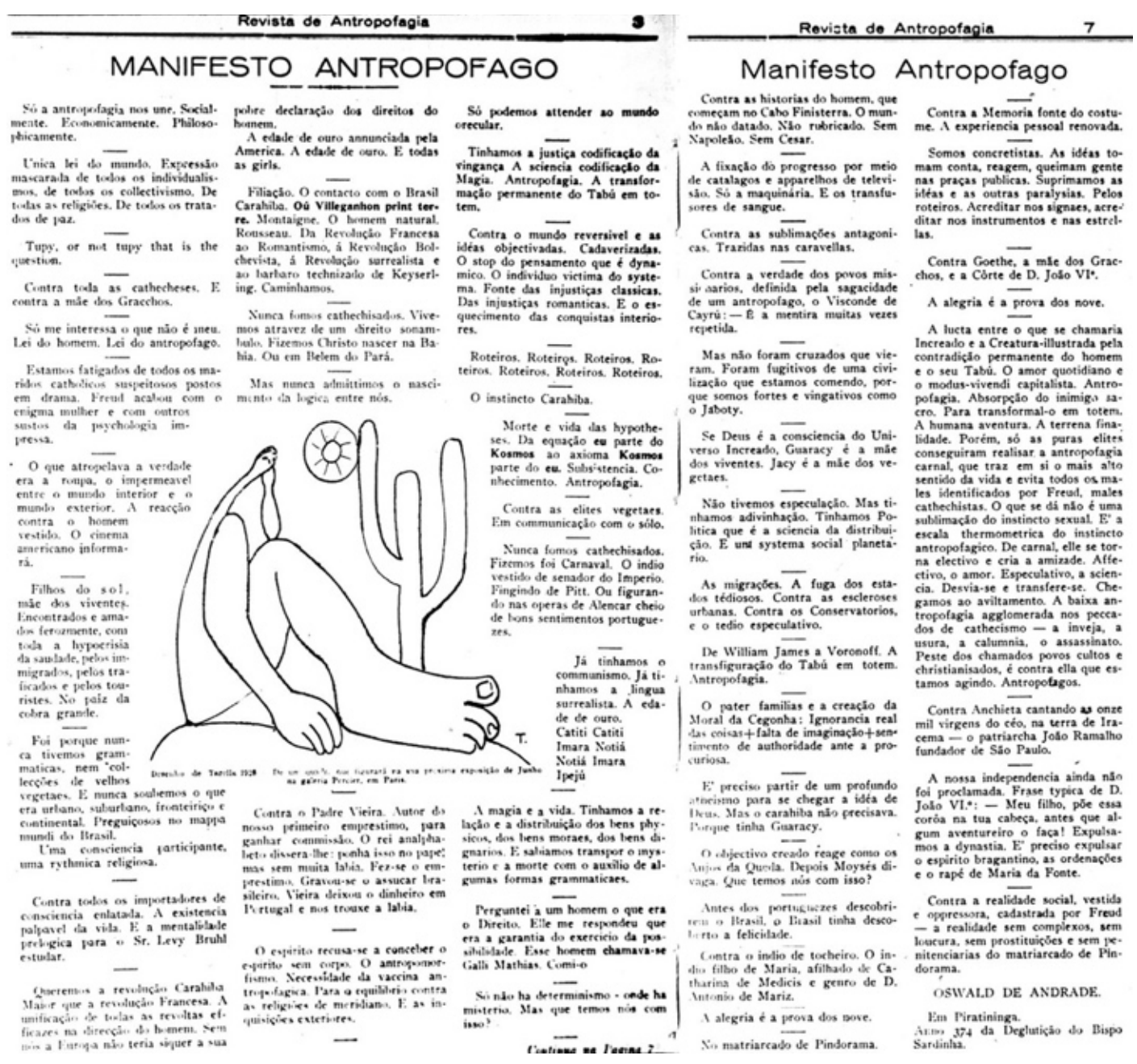

Figure 24: Picture of the Cannibalist Manifesto published in 1928.

It is often argued that this notion is best evoked in the line "Tupi or not Tupi."

Although the Manifesto was written in Portuguese, this line was purposefully written in English. Tupi, in this case, refers to the Native Americans of Brazil, while "To be or not to be" is also the opening of Shakespeare's Hamlet. As an act of cannibalism, De Andrade 'digests' the outside culture in the process of contextualizing into the Brazilian mindset. As observed by many, "this dual wordplay exhibits the interstices of European and Brazilian cultures and how inextricable the European influences became in 
Brazil." ${ }^{" 77}$ The appropriation of these parallel references allows for different sociological symbolisms, and I believe there is strong evidence that continues to be the country's greatest strength in the current Brazilian new media landscape, whether via silly memes or any other visual practice in online spaces.

Coupled with both the dramatistic pentad and the cannibalistic lens, the memes analyzed in this thesis shows a different pattern from those in the English-speaking world that are generally based on the repetition of the same visual texts with different short phrases. To a large extent, I believe the aforementioned agency of high intervisuality is related to the legacy of the Brazilian cultural cannibalism metaphor that intended to swallow and appropriate other cultural practices in the process of forging a genuine Brazilian way of making sense of the world. Moreover, I believe that the notion of cultural cannibalism is key in understanding the ways in which memes about the impeachment gain cultural meaning, and deserves close attention in discussions of new media practices in Brazil.

From the appropriation of the English language to the juxtaposition of international events or unrelated situations to the display of the hero and anti-hero dichotomies, digital labor is certainly one of the ways in which cannibalism will continue to exist. Furthermore, the three identified waves show the ways in which memes, as a media practice, illustrate realities and points of views that are often unheard, evoking to the popular saying, "when Brazilians find a new toy, they will play

\footnotetext{
77 "Cannibalist Manifesto." Aesthetic and Interpretive Understanding. Harvard University, FAS. Accessed April 28, 2018. https://coursewikis.fas.harvard.edu/aiu18/"Cannibalist_Manifesto".
} 
with it, take it apart, and mix it together with all their other favorites." ${ }^{\text {78 }}$ All in all, the Internet memes observed in the all waves illustrate Brazil's openness to hybrid crossfertilization of emerging media and several forms of culture, which is closely related to the cannibalism and telenovela conventions.

${ }^{78}$ Leonard, Andrew. "Brazil’s Orkut rule." Salon. Accessed April 25, 2017. http://www.salon.com/2008/01/14/brazil_s_orkut_rule/. 


\section{Chapter 6: Conclusion: Toward Participatory Politics}

Given the context of the 2016 Brazilian impeachment of Dilma Rouseff, the memes communicated through SNS reflected the country's division and growing frustration in politics. The appropriation of meme production and fast circulation as a response to the impeachment case served as a unique opportunity to study participatory culture in Brazil's new media landscape. In the previous chapters, I attempted to demonstrate how new media in Brazil may offer a new gateway for youth participation, given the development of ICTs and the influence of the Orkut Rule on those who often do not get to participate.

As I argued, the increased ability to participate in discussion in the political discourse, even via silly splashes of Internet humors as memes, offers a new way of not only becoming more civically active in cyberspace, but also playing an active role as mediamakers. Therefore, it is imperative to recognize memes as cultural artifacts that reflect the media universe in which they emerge and that gain meaning based on the specifics of the people interacting in that place, including their histories, forms of sociality, relationship with new media technologies, and perceptions of politics. The social critique, therefore, needs to focus on the societal conditions closely related to the people who create memes, and not on the text itself. In this case, memes are a mere reflection of the culture in which they emerge, either good or bad.

Additionally, I asserted that regardless of the political morality and legality behind the impeachment itself, the agency-purpose agency from Burke's pentad helps explain how Internet memes reflect the youth's logic when dealing with the political situation of the country. In doing so, there are arguably reoccurring elements from the 
local tradition of cultural cannibalism and popular imagination drawn from Brazilian telenovela conventions. The evidence for such claim lies in the melodrama unveiled by memetic messages over time, with rising action, heroes, villains, turning points, and a highly positive and hopeful resolution. While they not isolated determinants, they certainly play a signifcant role in the ways that citizens deploy new media, see their realities represented, and engage with civic-related issues.

Popular culture, in this sense, is the one of the major influences of this participation, which may lead one to critique the fact young people are apathetic of their political realities. While I think it is not totally untrue, I suggested that by empowering these youth to create media, they may exhort power in the public sphere, even if it is via humor and not directly via politics. By putting media makers in touch with the public sphere and other civic-related issues, new discussions may emerge and more voices can be taken into consideration when creating assumptions about the marginalized, policies for the common good, or anything else that involves the rights of young people in a democratic society. In this sense, my analysis of memes demonstrated how Brazilians adopted new media practices as an engaging instrument of power and opinion making under the continuing legacy of traditional media content such as telenovela and cannibalism.

Internet memes, therefore, serve as media participation that allows youth to appropriate, change, circulate, and consume information to transcend potential barriers that hinder discussions in the public sphere. This implies that memes alone hardly will be able to promote changes in the public sphere as they are only capable of fostering discussion through humor and popular culture. Moreover, I also believe that the 
findings also suggest that the media message in Internet memes do instigate strong discussions and participation in online and offline communities; however, the limitations lie in the fact that memes are far from representing a channel that effectively recommends or promotes civic action towards real change before an issue emerges in the public sphere.

Another interesting point is that the relationship between Internet memes during the impeachment and the discussions in the public sphere reveal how digital technology has been shaping political engagement among youth in Brazil. The use of memes during the impeachment provided an example of how fast Brazilian youth create, execute, and distribute new media as an alternative gateway for information that functions through participatory culture. Most of the memes analyzed in the research highlighted Brazil's cultural hybridity in using creative humor to either critique the incoherencies of the impeachment process or to support the removal of Rousseff from office.

For future research, it would be important to carry a study that identifies the key motivations youth have as media creators: what are some of the key ways in which Internet memes can shape political discussions with different stakeholders-from the family to the school environment? Additionally, further research needs to focus on a comparative study that investigates the production of political Internet memes versus other types of youth media texts. More important, and perhaps more challenging job will be to identify and advocate new media practices that would continue to promoting the political awareness among Brazilian youth, as initiated by Internet memes. This way, Internet memes can partake a significant role that is meaningful not only to have 
fun, but also to discuss issues regarding politics, civic engagement, democracy, and so forth.

Although not all memes reflected youth's will and sagacity in discussing politics, the collective debate through memes during the impeachment suggests that Brazilian youth can reflect about issues of democracy by using humor in a way that potentially triggers further discussions in the public sphere. This suggests that Brazilian youth are not passive consumers of traditional media, but rather active, creative, and influential in online spaces and, potentially, in the public sphere.

Regardless of the media message of each specific meme created as a response to the impeachment process, the youth creative process and the circulation of these memes on Facebook and Twitter represented a diffusion of ideas that operate under intertextuality, powerful dialogue, and self-irony. Given the popular dimension of Internet memes among Brazilian youth, it is likely that the legacy of the memes circulated during the 2016 impeachment will impact the way historians of the future study youth engagement as well as the emergence of unique and creative new media practices. 


\section{Bibliography}

“Al Jazeera Helps Shape Political Identity of Arabs, Study Finds." Ohio State University, November 18, 2010. https://news.osu.edu/news/2010/11/18/arabnetworks/

"Cannibalist Manifesto.” Aesthetic and Interpretive Understanding. Harvard University, FAS. https://coursewikis.fas.harvard.edu/aiu18/"Cannibalist_Manifesto".

"Fixed broadband subscriptions (per 100 people)." Fixed broadband subscriptions (per 100 people) | World Bank, 2015. http://data.worldbank.org/indicator/IT.NET.BBND.P2?end=2015\&locations=B R\&start $=1990 \&$ view $=$ chart.

"Rede Globo emite conteúdos em Angola e Moçambique exclusivamente pela ZAP." SAPO 24, June 02, 2015. http://24.sapo.pt/noticias/nacional/artigo/rede-globo-emite-conteudos-emangola-e-mocambique-exclusivamente-pela-zap_19311208.html.

"Twitter divulga infográfico com perfil do usuário brasileiro.” Aba.com.br. November 24, 2015. Accessed March 30, 2017. http://www.aba.com.br/canais/midia/artigos/twitter-divulga-infografico-comperfil-do-usuario-brasileiro.

"88\% dos internautas brasileiros assistem TV e navegam na internet ao mesmo tempo." IBOPE Brasil, accessed May 15, 2017. http://www.ibope.com.br/pt-br/noticias/Paginas/88-dos-internautas-brasileirosassistem-TV-e-navegam-na-internet-ao-mesmo-tempo-.aspx.

"Word of the Year 2017 Is..." Oxford Dictionaries | English. Accessed May 01, 2018. https://en.oxforddictionaries.com/word-of-the-year/word-of-the-year-2017.

Chao, Loretta. "Brazil: The Social Media Capital of the Universe." The Wall Street Journal. February 04, 2013. Accessed May 15, 2017. https://www.wsj.com/articles/SB10001424127887323301104578257950857891 898.

Dawkins, Richard. The Selfish Gene. New ed. Oxford; New York: Oxford University Press, 1989.

Facebook \#CPBR9. Performed by Ime Archibong. January 29, 2016. Accessed March 29, 2017. https://www.youtube.com/watch?v=OSADQZ9XOwA. 
Farber, Madeline. "The Internet Officially Cares More About Memes Than Jesus." Google Trends 2016: Memes More Popular Than Jesus |Fortune.com. October 27, 2016. Accessed May 14, 2017.

Hhttp://fortune.com/2016/10/27/google-trends-memes-jesus/.

Fastenberg, Dan. “Why Is Twitter So Popular in Brazil?” Time. October 20, 2010. Accessed March 30, 2017. http://content.time.com/time/world/article/0,8599,2026442,00.html.

Fenez, Marcel, and Estela Vieira. Brazil: Leading the Digital Media Revolution in Latin America. Report. PricewaterhouseCoopers . 2014. Accessed February 26, 2017. http://www.pwc.com/gx/en/global-entertainment-media-outlook/assets/brazilsummary.pdf.

Flávia Villela, "IBGE: 40\% Dos Brasileiros Têm Televisão Digital Aberta." Agência Brasil.

Freire, Fernanda. Uma Breve Reflexão Sobre Memes Políticos, Humor e Conversação Cotidiana Informal. Universidade Federal de Minas Gerais. Opinião Pública. August 2016. Accessed April 1, 2017. http://opiniaopublica.ufmg.br/site/files/artigo/3-Fernanda-Freire-REV.pdf.

Horst, Heather A. "Free, Social, and Inclusive: Appropriation and Resistance of New Media Technologies in Brazil." International Journal of Communication 5 (2011): 437-62.

Jenkins, Henry. Confronting the Challenges of Participatory Culture: Media Education for the 21st Century. John D. and Catherine T. MacArthur Foundation Reports on Digital Media and Learning. Cambridge, MA: MIT Press, 2009.

La Nueva Revolucion Digital. Publication. Unidad de Innovación y Nuevas Tecnologías de la División de Desarrollo Productivo y Empresarial, Comisión Económica para América Latina y el Caribe. Santiago: United Nations, 2016.

Lemos, Ronaldo, and Paula Martini. LAN Houses: A New Wave of Digital Inclusion in Brazil. Report. Center for Technology and Society, Fundação Getulio Vargas Law School. Accessed March 29, 2017. http://publius.cc/lan_houses_new_wave_digital_inclusion_brazil/091509

Lopes, Maria Immacolata Vassalo de Lopes I. V. "Telenovela as a Communicative Resource." Matrizes 3, no. 1 (2009): 3. Accessed March 4, 2017.

McCann, Bryan. The Throes of Democracy: Brazil since 1989. Global History of the Present. Halifax, Nova Scotia: London; New York: New York: Fernwood Pub.; Zed Books; Distributed in the USA Exclusively by Palgrave Macmillan, 2008. 
Mesquita, Bruna. " $90 \%$ dos jovens brasileiros possuem pelo menos um perfil nas redes sociais | EXAME.com - Negócios, economia, tecnologia e carreira.” July 29, 2015. Accessed February 26, 2017. http://exame.abril.com.br/tecnologia/90-dosjovens-brasileiros-possuem-pelo-menos-um-perfil-proprio-em-rede-social.

Ok, HyeRyoung. "New Media Practices in Korea." International Journal of Communication 5 (2011): 320-48.

Oliveira, Omar S. Brazilian soaps outshine Hollywood: is cultural imperialism fading out? In: Nordenstreng K, Schiller HI (eds) Beyond National Sovereignty: International Communication in the 1990s. Norwood, NJ: Ablex, 116-131.

Page, Joseph A. The Brazilians. Reading, Massachusetts: Addison-Wesley Publishing Company, 1995.

Pesquisa Brasileira de Mídia 2015: Hábitos de Consumo de Mídia Pela População Brasileira. Publication. Secretaria de Comunicação Social, Presidência da República. Brasília: Secom, 2014.

Pignatari, Décio. Signagem da televisão. Sao Paulo: Brasiliense, 1984.

Recuero, Raquel. "Social Media in South America: Orkut \& Brazil.” DML Central. June 08, 2016. Accessed April 27, 2017. https://dmlcentral.net/social-media-in-south-america-orkut-brazil/.

Rheingold, Howard. Net Smart: How to Thrive Online. Cambridge, MA: MIT Press, 2012.

Ruvolo, Julie. "Why Brazil Is Actually Winning The Internet.” BuzzFeed. June 29, 2014. Accessed April 17, 2018. https://www.buzzfeed.com/jruv/why-brazil-is-actually-winning-theinternet?utm_term=.qeaBVR0RXo\#.rlYqVk5kew.

Shifman, Limor. Memes in Digital Culture. MIT Press Essential Knowledge Series. Cambridge, Massachusetts: MIT Press, 2014.

Simon, Jean P. The ICT Landscape in BRICS Countries: Brazil, India, China. Report. Institute for Prospective Technological Studies, European Commission. Luxembourg: Publications Office of the European Union, 2011.

Soep, Elisabeth. Participatory Politics: Next-generation Tactics to Remake Public Spheres. John D. and Catherine T. MacArthur Foundation Reports on Digital Media and Learning. Cambridge, Massachusetts; London: MIT Press, 2014. 
Sputnik. "Weird War of Memes Bursts Out Between Brazil and Portugal." Sputnik International - Breaking News \& Analysis - Radio, Photos, Videos, Infographics. June 18, 2016. Accessed May 14, 2017. https://sputniknews.com/world/201606181041569190-brazil-portugal-warmemes/.

Tongia, Rahul, Eswaran Subrahmanian, and V. S. Arunachalam. Information and Communications Technology for Sustainable Development: Defining a Global Research Agenda. Report. Carnegie Mellon University. Mumbai: Allied Publishers PVt. Ltd., 2004. 29-30. http://www.cs.cmu.edu/ rtongia/ICT4SD_Full_Book.pdf

Tsang, Flavia, Ohid Yaqub, Desiree Van Welsum, Tony G. Thompson-Starkey, and Joanna Chataway. The Impact of Information and Communication Technologies in the Middle East and North Africa. Report. World Bank. Accessed November 05, 2016.

Tufte, Thomas. Living with the Rubbish Queen: Telenovelas, Culture and Modernity in Brazil. Luton, Bedfordshire, UK: University of Luton Press, 2000.

"Why spreadable doesn't equal viral: A conversation with Henry Jenkins.” Nieman Lab. Accessed April 07, 2017. http://www.niemanlab.org/2010/11/why-spreadable-doesnt-equal-viral-aconversation-with-henry-jenkins/.

Wittel, Andreas. "Toward a Network Sociality.” Theory Culture and Society 18, no. 6 (2001). 